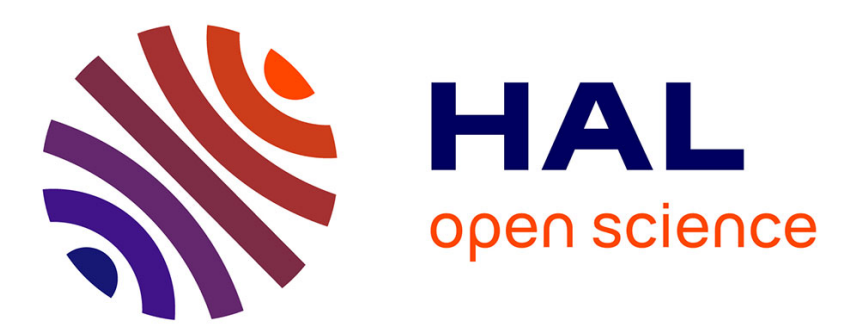

\title{
Factors affecting the long-term stability of mesoporous nickel-based catalysts in combined steam and dry reforming of methane
}

\author{
K. Jabbour, N. El Hassan, A. Davidson, S. Casale, Pascale Massiani
}

\section{To cite this version:}

K. Jabbour, N. El Hassan, A. Davidson, S. Casale, Pascale Massiani. Factors affecting the longterm stability of mesoporous nickel-based catalysts in combined steam and dry reforming of methane. Catalysis science and Technology, 2016, 6 (12), pp.4616-4631. 10.1039/C6CY00032K . hal-01346456

\section{HAL Id: hal-01346456 \\ https://hal.sorbonne-universite.fr/hal-01346456}

Submitted on 19 Jul 2016

HAL is a multi-disciplinary open access archive for the deposit and dissemination of scientific research documents, whether they are published or not. The documents may come from teaching and research institutions in France or abroad, or from public or private research centers.
L'archive ouverte pluridisciplinaire HAL, est destinée au dépôt et à la diffusion de documents scientifiques de niveau recherche, publiés ou non, émanant des établissements d'enseignement et de recherche français ou étrangers, des laboratoires publics ou privés. 


\title{
Catalysis Science \& Technology
}

\section{Factors affecting the long-term stability of mesoporous nickel- based catalysts in combined steam and dry reforming of methane}

\begin{abstract}
K. Jabbour, ${ }^{a, b}$ N. El Hassan, ${ }^{a^{*}}$ A. Davidson, ${ }^{b}$ S. Casale ${ }^{b, c}$ and P. Massiani ${ }^{b, c^{*}}$
An ordered mesoporous "one-pot" nickel-alumina catalyst (5 wt\% Ni) was synthesized using the evaporation-induced selfassembly method. Compared to an impregnated and to a non-porous catalysts, the ordered "one-pot" Ni-alumina sample displayed, after in-situ reduction, the highest and the most stable catalytic performances along $40 \mathrm{~h}$ of run at $800^{\circ} \mathrm{C}$ in combined steam and dry reforming of methane, with conversion and selectivity values close to the thermodynamic expected-ones. Both the confinement of well-dispersed Ni-nanoparticles within the structured $\mathrm{Al}_{2} \mathrm{O}_{3}$ framework and the strengthened $\mathrm{Ni}$-support interaction compared to other catalysts are shown to be key factors accounting for the high catalytic activity and stability. Contrarily to alumina that appears as an effective support of Ni for catalytic combined methane reforming, neither mesoporous (SBA-15) nor macroporous (CeliteS, diatoms) silica are appropriate ones due to rapid deactivation by partial reoxidation of the metallic $\mathrm{Ni}^{0}$ active phase in the conditions of reaction.
\end{abstract}

\section{Introduction}

Nowadays, combined steam and dry reforming of methane (CSDRM) to synthesis gas (syngas, $\mathrm{H}_{2}$ and $\mathrm{CO}$ mixture) is gaining significant attention. This process enables the production of syngas from renewable energy sources such as biogas whose main components are methane, carbon dioxide and water. $^{1}$ Simultaneously, this reaction allows the conversion of two major greenhouse gases $\left(\mathrm{CH}_{4}\right.$ and $\left.\mathrm{CO}_{2}\right)$ into valuable gaseous mixtures, largely utilized as feedstock for the production of synthetic fuels and of chemical intermediates in petrochemical industries. ${ }^{2}$ The product ratio of hydrogen to carbon monoxide is 3 in conventional steam reforming of methane (SRM, $\mathrm{CH}_{4}+\mathrm{H}_{2} \mathrm{O} \rightarrow 3 \mathrm{H}_{2}+\mathrm{CO}$ ) and 1 in dry reforming of methane (DRM, $\mathrm{CH}_{4}+\mathrm{CO}_{2} \rightarrow 2 \mathrm{H}_{2}+2 \mathrm{CO}$ ). However, applications involving syngas for subsequent utilization in methanol synthesis (syngas being then called metgas) require a $\mathrm{H}_{2} / \mathrm{CO}$ product ratio close to $2\left(2 \mathrm{H}_{2}+\mathrm{CO} \rightarrow \mathrm{CH}_{3} \mathrm{OH}\right) .{ }^{1}$ Such ratio may be also desired in some Fisher-Tropsch (FT) operations (e.g. $(2 n+1) \mathrm{H}_{2}+n \mathrm{CO} \rightarrow \mathrm{C}_{n} \mathrm{H}_{(2 n+2)}+n \mathrm{H}_{2} \mathrm{O}$ ) where the optimum reactant ratio $\left(\mathrm{H}_{2} / \mathrm{CO}:(2 n+1) / n\right)$ should be around 2 for large $n$ values. ${ }^{1,3}$ In such case, the CSDRM process $\left(\mathrm{CH}_{4}+1 / 3 \mathrm{CO}_{2}+2 / 3\right.$ $\mathrm{H}_{2} \mathrm{O} \rightarrow 8 / 3 \mathrm{H}_{2}+4 / 3 \mathrm{CO}$ ) appears as a promising one-step approach giving an $\mathrm{H}_{2} / \mathrm{CO}$ ratio around 2 and it is nowadays considered as an effective alternative to other reforming reactions, ${ }^{4}$ also allowing easy adjustment of the initial $\mathrm{CH}_{4} / \mathrm{CO}_{2} / \mathrm{H}_{2} \mathrm{O}$ feed composition. ${ }^{1 \mathrm{c}, 5}$ By comparison, both

\footnotetext{
${ }^{a}$ Department of Chemical Engineering, Faculty of Engineering, University of Balamand, POBox 100,Tripoli, Lebanon, nissrine.hassan@balamand.edu.lb

b. Sorbonne Universités, UPMC Université Paris 06, Laboratoire de Réactivité de Surface, 4 place Jussieu, 75005 Paris, France.

CNRS UMR 7197, UPMC, Laboratoire de Réactivité de Surface, 4 place Jussieu, 75005 Paris, France, pascale.massiani@upmc.fr
}

methane partial oxidation ( $\mathrm{POM}, \mathrm{CH}_{4}+1 / 2 \mathrm{O}_{2} \rightarrow 2 \mathrm{H}_{2}+\mathrm{CO}$ ) and auto-thermal reforming (ATR, $\mathrm{CH}_{4}+1 / 4 \mathrm{O}_{2}+1 / 2 \mathrm{H}_{2} \mathrm{O} \rightarrow 5 / 2 \mathrm{H}_{2}$ $+\mathrm{CO}$ ) can also produce a ratio near 2 , but these processes, which involve oxygen, are more expensive and more difficult to control since the reactions can lead to local hot spots with associated dangers of explosions. ${ }^{4}$

Various supported monometallic catalysts have been studied for CSDRM and the available literature is summarized in Table 1. Amongst already tested active phases, a patent by Yagi et al. ${ }^{6}$ devoted to noble-metals (Ru /or Rh) supported on a basic support revealed steady performances for extended periods of time (up to $1000 \mathrm{~h}$ ) at elevated pressures. However, with consideration of the high cost and limited availability of noble metals, their substitution by transition ones, such as $\mathrm{Ni}$ or $\mathrm{Co}$, is desirable for large-scale applications and several works report high initial activities (table 1). Transition metals are, however, less stable than noble metals even if several tactics were already employed to enhance their time on stream (TOS) performances by limiting the sintering and/or coke deposition processes known to be the main causes of potential deactivation. Olah et al. $^{1 \mathrm{a}, 1 \mathrm{~b}}$ developed effective $\mathrm{Ni}$ (or $\mathrm{Co}$ ) dispersed on $\mathrm{MgO}$ catalysts for the targeted reaction (called bireforming in their papers) and reported performances significantly higher than those obtained on a $\mathrm{Rh} / \mathrm{MgO}$ catalyst. ${ }^{5 \mathrm{~b}, 5 \mathrm{c}}$ The high activity was attributed to the formation of a solid-solution between the metal and the MgO support, leading to a stabilization of the nanoparticles during the run. Besides $\mathrm{MgO}$, hydrotalcite like-materials decomposed into mixed oxides stand out as typical supports for Ni species (Table 1) with high activity and selectivity in CSDRM. $^{9(a, c)}$ Similarly, Roh et al. ${ }^{5 a}$ and Koo et al. ${ }^{9 a}$ ascribed the enhanced performance of their hydrotalcite-based catalysts compared to $\mathrm{Al}_{2} \mathrm{O}_{3}, \mathrm{CeO}_{2}$ and $\mathrm{ZrO}_{2}$ based-ones (Table 1) to a higher dispersion of nickel nanoparticles resulting in an enhanced metal-support interaction (MSI). 


\begin{tabular}{|c|c|c|c|c|c|c|c|c|c|c|c|c|}
\hline \multirow{3}{*}{$\begin{array}{l}\text { Catalytic } \\
\text { support }\end{array}$} & \multirow{3}{*}{ Metal } & \multicolumn{2}{|c|}{ Active phase } & \multicolumn{5}{|c|}{ Reactivity, selectivity } & \multicolumn{4}{|c|}{ Remarks } \\
\hline & & \multirow{2}{*}{ wt\% } & \multirow{2}{*}{ Deposition* } & \multicolumn{2}{|c|}{$X(\%)$} & \multirow[t]{2}{*}{$\mathrm{H}_{2} / \mathrm{CO}$} & \multirow[t]{2}{*}{$\mathrm{Rr}^{* *}$} & \multirow[t]{2}{*}{$\mathrm{T}\left({ }^{\circ} \mathrm{C}\right)$} & \multirow{2}{*}{$\begin{array}{l}\mathrm{P} \\
\text { (bar) }\end{array}$} & \multicolumn{2}{|c|}{ Stability/selectivity*** } & \multirow[t]{2}{*}{ Ref } \\
\hline & & & & $\mathrm{CH}_{4}$ & $\mathrm{CO}_{2}$ & & & & & Cat. & Improving method & \\
\hline \multirow{5}{*}{$\mathrm{MgO}$} & $\mathrm{Ni}$ & 15 & \multirow{5}{*}{ Imp. } & 71 & 72 & 1.99 & \multirow{3}{*}{$1 / 0.4 / 0.8$} & 830 & 7 & SS & --- & $1 a$ \\
\hline & $\mathrm{Ni}$ & 15 & & 88 & 92 & 1.97 & & 830 & 1 & SS & -- & $1 b$ \\
\hline & Co & 15 & & 70 & 64 & 1.96 & & 830 & 7 & SS & --- & $1 b$ \\
\hline & $\mathrm{Ni}$ & 12 & & 60 & n.m. & n.m. & & 800 & 1 & --- & Change support to $\mathrm{MgO}-\mathrm{Al}_{2} \mathrm{O}_{3}$ & $5 a$ \\
\hline & $\mathrm{Ru}$ & 0.5 & & 70 & n.m. & n.m. & $1 / 0.3 / 0.7$ & 900 & 1 & --- & n.m. & $5(b, c)$ \\
\hline Basic (n.m.) & $\mathrm{Ru}, \mathrm{Rh}$ & n.m. & n.m. & n.m. & n.m. & n.m. & n.m. & n.m. & 20 & SS & 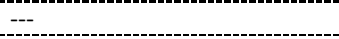 & 6 \\
\hline \multirow{11}{*}{$\mathrm{Al}_{2} \mathrm{O}_{3}$} & $\mathrm{Ni}$ & n.m. & n.m. & 72 & n.m. & n.m. & $1 / 0.4 / 0.8$ & 800 & & --- & Change support to $\mathrm{MgO}-\mathrm{Al}_{2} \mathrm{O}_{3}$ & $5 a$ \\
\hline & Co & 5 & \multirow{8}{*}{ Imp. } & 95 & 71 & 1.20 & $1 / 1 / 0.2$ & 700 & & SS & --- & $7 a$ \\
\hline & & 10 & & 81 & n.m. & n.m. & & 800 & & --- & Change support to $\mathrm{CeO}_{2}-\mathrm{ZrO}_{2}$ & $7 b$ \\
\hline & & 12 & & 75 & n.m. & n.m. & & 750 & & --- & 20 wt\% MgO & 7c \\
\hline & & 12 & & 61 & 50 & n.m. & $1 / 0.4 / 0.8$ & 700 & 1 & --- & 6 wt\% $\mathrm{CeO}_{2}$ & $7 d$ \\
\hline & & 7 & & 94 & 76 & 2.08 & & 850 & 1 & --- & Treatment step & \\
\hline & $\mathrm{Ni}$ & 7 & & $98^{[\wedge]}$ & $83^{[\wedge]}$ & $2.02^{[\wedge]}$ & & 850 & & SS & -- & $7 e$ \\
\hline & & 4 & & 89 & 49 & 1.49 & $1 / 0.3 / 0.7$ & 750 & & $\mathrm{~S}$ & --- & $7 f$ \\
\hline & & 15 & & 95 & 90 & 1.10 & $1 / 1 / 0.16$ & 750 & & --- & $12 \mathrm{wt} \% \mathrm{MgO}$ & $7 g$ \\
\hline & & 10 & O.P. & 92 & 76 & 2.70 & $1 / 0.3 / 0.7$ & 800 & & $\mathrm{~S}$ & n.m. & $7 \mathrm{~h}$ \\
\hline & $\mathrm{Ni}, \mathrm{Ti}^{[+]}$ & n.m. & n.m. & n.m. & n.m. & n.m. & n.m. & n.m. & n.m. & SS & --- & 8 \\
\hline & & 12 & Imp. & 92 & n.m. & n.m. & & 800 & & SS & -- & $5 a$ \\
\hline & & n.m. & n.m. & 91 & 90 & 1.90 & & 800 & & --- & Calcination $\mathrm{T}\left({ }^{\circ} \mathrm{C}\right)$ & רa \\
\hline & & 12 & Imp. & 92 & 93 & 1.90 & & 800 & & SS & -- & $9 a$ \\
\hline & & 10 & & 77 & 62 & 2.20 & $1 / 0.4 / 0.8$ & 700 & 1 & --- & $2.5 \mathrm{wt} \% \mathrm{CeO}_{2}$ & $9 b$ \\
\hline $\mathrm{MgO}_{(\mathrm{x})}-\mathrm{Al}_{2} \mathrm{O}_{3(\mathrm{y})}$ & & & & $97^{[-]}$ & $7^{[-]}$ & $2.10^{[-]}$ & & 750 & & --- & $(\mathrm{Mg} / \mathrm{Al})$ ratio & \\
\hline $\mathrm{x}: 30, \mathrm{y}: 70 \mathrm{wt} \%$ & $\mathrm{NI}$ & 12 & & 97 & 84 & 2.00 & & 750 & & SS & --- & $9 \mathrm{c}$ \\
\hline & & & & 85 & 47 & 2.27 & & 850 & & --- & 4 wt\% $\mathrm{CeO}_{2}$ & $9 d$ \\
\hline & & 15 & & 74 & 35 & 2.22 & $1 / 0.4 / 1$ & 850 & 10 & --- & $15 \mathrm{wt} \%\left(\mathrm{CeO}_{2}-\mathrm{ZrO}_{2}\right)$ & $9 e$ \\
\hline & & & & 95 & 90 & n.m. & $1 / 1 / 0.16$ & 750 & 1 & --- & $10 \mathrm{wt} \% \mathrm{La}_{2} \mathrm{O}_{3}$ & $9 f$ \\
\hline & & 10 & O.P. & 94 & 74 & 2.80 & $1 / 0.3 / 0.7$ & 800 & & $\mathrm{~S}$ & n.m. & $7 \mathrm{~h}$ \\
\hline & & 12 & & 57 & n.m. & n.m. & & 800 & & --- & Change support to $\mathrm{MgO}-\mathrm{Al}_{2} \mathrm{O}_{3}$ & $5 a$ \\
\hline $\mathrm{CeO}_{2}$ & $\mathrm{Ni}$ & 15 & Imp. & 58 & n.m. & n.m. & $1 / 0.4 / 0.8$ & 800 & 1 & --- & Change support to $\mathrm{CeO}_{2}-\mathrm{ZrO}_{2}$ & 10 \\
\hline & & 12 & & 64 & n.m. & n.m. & & 800 & & --- & Change support to $\mathrm{MgO}-\mathrm{Al}_{2} \mathrm{O}_{3}$ & $5 a$ \\
\hline $\mathrm{ZrO}_{2}$ & $\mathrm{Ni}$ & 15 & Imp. & 63 & n.m. & n.m. & $1 / 0.4 / 0.8$ & 800 & 1 & --- & Change support to $\mathrm{CeO}_{2}-\mathrm{ZrO}_{2}$ & 10 \\
\hline $\mathrm{Ce}_{(\mathrm{x})} \mathrm{Zr}_{(\mathrm{y})} \mathrm{O}_{2}$ & $\mathrm{Ni}$ & 15 & O.P. & 97 & 80 & n.m. & & 800 & & SS & -- & $7 \mathrm{~b}$ \\
\hline$x: 80, y: 20 w t \%$ & $\mathrm{NI}$ & 15 & Imp. & 94 & n.m. & n.m. & $1 / 0.4 / 0.8$ & 800 & 1 & SS & -- & 10 \\
\hline & $\mathrm{Ni}, \mathrm{Ti}^{[+]}$ & n.m. & n.m. & n.m. & n.m. & n.m. & n.m. & n.m. & n.m. & SS & -- & 8 \\
\hline $\mathrm{SIO}_{2}$ & $\mathrm{Ni}$ & 10 & Imp. & $98^{[!]}$ & $86^{[!]}$ & $1.74^{[!]}$ & $1 / 0.5 / 0.75$ & 850 & 1 & --- & 3 wt\% MgO & 11 \\
\hline $\mathrm{Nd}_{2} \mathrm{O}_{3}$ & Co & 29 & O.P. & 73 & 86 & 2.40 & $1 / 0.35 / 0.7$ & 850 & 1 & $\mathrm{~S}$ & n.m. & $5 d$ \\
\hline $\mathrm{CaO}$ & $\mathrm{Ni}$ & 23 & O.P. & 92 & 80 & 1.58 & $1 / 0.5 / 0.5$ & 800 & 1 & SS & - & $5 e$ \\
\hline MgO-SA-525 & $\mathrm{Ni}$ & 13.6 & Imp. & 98 & 82 & 1.70 & $1 / 0.5 / 0.5$ & 800 & 1 & SS & - & $5 f$ \\
\hline Carbide & Mo & 5 & O.P. & $91^{[!]}$ & $\begin{array}{l}\text { n.m. } \\
\text { n.m. }\end{array}$ & $\begin{array}{l}2.00^{[]^{-}} \\
1.97^{[!]}\end{array}$ & $1 / 0.3 / 0.7$ & 900 & 8.7 & $\begin{array}{l}\text { SS } \\
\text { SS }\end{array}$ & -- & $5 g$ \\
\hline $\begin{array}{l}\mathrm{Al}_{2} \mathrm{O}_{3(\mathrm{x})}-\mathrm{SiC}_{(\mathrm{y})} \\
\mathrm{x}: 10, \mathrm{y}: 95 \mathrm{wt} \%\end{array}$ & $\mathrm{Ni}$ & 12 & Imp. & 96 & 48 & 1.84 & $1 / 0.34 / 1.2$ & 850 & 1 & SS & -- & 12 \\
\hline $\begin{array}{l}\mathrm{pNirb}+\mathrm{MgO}_{(\mathrm{x})} \\
\mathrm{x}: 4 \mathrm{wt} \%\end{array}$ & $\mathrm{Ni}$ & 4 & Imp. & 57 & n.m. & 1.84 & $1 / 0.65 / 1.2$ & 750 & 1 & $\mathrm{~S}$ & n.m. & 13 \\
\hline Ni plate & $\mathrm{Ni}$ & n.m. & O.P. & 94 & -19 & 3.40 & $1 / 0.33 / 1$ & 750 & 1 & $\mathrm{~S}$ & n.m. & 14 \\
\hline $\mathrm{ZrO}_{2}-\mathrm{La}_{2} \mathrm{O}_{3}$ & $\mathrm{Ru}$ & 4 & Imp. & 25 & n.m. & n.m. & $1 / 1 / 5$ vol\% & 500 & 1 & SS & -- & $15 a$ \\
\hline $\begin{array}{l}\text { *: Metal deposit } \\
* *: \text { Molar comp } \\
* * *: \text { Catalysts (C } \\
\text { n.m.: not mentic } \\
{[+]: \text { In addition t }} \\
{[\wedge]: \text { Steam pretr }} \\
{[-]: \text { Ni//MgO-Al }} \\
\text { [!]: Designate ca } \\
\text { [\$]: MgO-SA-525 } \\
\text { [\#]: pNirb+xMgO }\end{array}$ & $\begin{array}{l}\text { l by post- } \\
\text { tion of fe } \\
\text { ) stable } \\
\text { ed } \\
\text { he ment } \\
\text { ted } \mathrm{Ni} / \mathrm{Al} \\
\text { with } \mathrm{Mg} \\
\text { lysts havi } \\
\text { upport is } \\
\text { cands for }\end{array}$ & $\begin{array}{l}\text { ipregnat } \\
\text { ding reac } \\
\text { d selecti } \\
\text { hed meta } \\
{ }_{3} \text { sample } \\
\text { Al (molar } \\
\text { support } \\
\text { mposed } \\
\text { rous nic }\end{array}$ & $\begin{array}{l}\text { n (Imp.) on the } \\
\text { nts }\left(\mathrm{CH}_{4} / \mathrm{CO}_{2} / \mathrm{l}\right. \\
\text { (SS) or stable } \\
\text { the list includ } \\
\text { reparation de } \\
\text { tio) of } 3.5 \\
\text { with organized } \\
\text { lainly of alumir } \\
\text { ribbon coate }\end{array}$ & $\begin{array}{l}\text { upport } \\
\text { O- mol/ } \\
\text { it not se } \\
: \mathrm{V}, \mathrm{Mn} \\
\text { ils are } \mathrm{n} \\
\text { orous st } \\
\text { (86.1 W } \\
\text { with } \mathrm{Mg}\end{array}$ & $\begin{array}{l}\text { by one } \\
\text { lol/mol) } \\
\text { ctive (S } \\
\text { Ga, Ca, } \\
\text { entione } \\
\text { uctures } \\
\text { \%) and } \\
\text { layer }\end{array}$ & $\begin{array}{l}\text { ot (O.P.) } \\
\text { under re } \\
\text { o, Bi, Co, } \\
\text { in the cor } \\
\text { micro and } \\
\text { ica (11.8 }\end{array}$ & $\begin{array}{l}\text { the course o } \\
\text { tion condition } \\
\text { b, Zr, La, Sn } \\
\text { esponding ref } \\
\text { or mesostruct } \\
\text { t\%) and is pre }\end{array}$ & $\begin{array}{l}\text { suppor } \\
\text {; propo } \\
\text { ence } \\
\text { re) } \\
\text { oated }\end{array}$ & nthes & of an & (5.1 wt\%) & \\
\hline
\end{tabular}

[\#]: pNirb+xMgO stands for porous nickel ribbon coated with $\mathrm{MgO}$ layer

In addition to the incorporation of promoters with specific properties (Table 1), some of the newest strategies for the development of stable and selective catalysts involve the usage of "original" supports able to improve MSI, such as silicon carbide
$(\mathrm{SiC})^{12}$ or porous Ni-plates, ${ }^{13}$ yet considered and in an extensive way in the case of DRM and SRM reactions.

The list of reforming catalysts based on $\mathrm{Ni}$ dispersed on different supports includes as well the conventional oxide that is alumina, which generally provides superior initial activities (in terms of $\mathrm{CH}_{4}$ and $\mathrm{CO}_{2}$ conversions) ${ }^{7}$ than those recorded on $\mathrm{CeO}_{2},{ }^{5 a, 10} \mathrm{ZrO}_{2},{ }^{5 a, 10}$ or 
$\mathrm{MgO}^{5 \mathrm{a}}$ under stoichiometric feed of gases. Nevertheless, in addition to patented studies, many works point out that, due to the high endothermic character of the reaction ${ }^{15}$ (generally conducted at $\mathrm{T} \geq$ $750^{\circ} \mathrm{C}$, Table 1 ), $\mathrm{Ni}$ dispersed on $\mathrm{Al}_{2} \mathrm{O}_{3}$ catalysts currently suffer from the major drawback of deactivation, thus resulting in rapid losses of activity. ${ }^{5 a, 7(a, c, d, e, g)}$ Even if stable, some $\mathrm{Al}_{2} \mathrm{O}_{3}$-based catalysts also demonstrated lack of selectivity, giving $\mathrm{H}_{2} / \mathrm{CO}$ molar ratios different from 2 in spite of conditions expected to favor such ratio. $^{7(f, h)}$ As lately reviewed by Li et al., ${ }^{[16]}$ the main orientation towards catalytic development is shifting towards monometallic supported catalysts characterized by highly dispersed metallic nanoparticles and strengthened MSI. Achieving such properties should effectively hinder the deactivation process by providing continuous accessibility to the active sites, along with reduced coking kinetics over size-controlled particles smaller than a "critical size". However, maintaining a high dispersion of $\mathrm{Ni}$-particles with nano-scale dimensions over the support under harsh reduction and reaction conditions is a challenging task, yet it is a priority for reforming reactions especially those conducted in presence of steam where sintering becomes highly favored. ${ }^{17}$ In this context, an improved $\mathrm{Ni} / \mathrm{Al}_{2} \mathrm{O}_{3}$ catalyst was developed by Son et al. ${ }^{7 \mathrm{e}}$ by enhancing the interaction of $\mathrm{Ni}$ with their commercial alumina support after an additional steam treatment session $\left(\mathrm{H}_{2} / \mathrm{H}_{2} \mathrm{O}\right)$ following a $\mathrm{H}_{2}$-reduction one, and they obtained an effective combined reforming catalyst with enhanced coking and sintering limitations.

Another promising approach is the confinement of well-dispersed nano-particles within standard oxides having ordered mesoporous channels, to stabilize and minimize their growth during reaction and thus allow preserving a stable reactivity on TOS. In the previous literature, Ni-loaded mesoporous catalysts based on SBA-15 silica or mesoporous $\mathrm{Al}_{2} \mathrm{O}_{3}$ displayed ascendant catalytic activity for both the dry and the steam reforming reactions ${ }^{18,19}$ owing to the special structural features of these supports. Despite the particular properties of ordered-structured materials and the expectation of promising performances even in combined reforming conditions, ${ }^{5 g}$ the literature dealing with the preparation of such oxides for their application in CSDRM is still very limited (table 1). In addition, there exists to our knowledge no work establishing correlation between the catalytic performances and the physicochemical properties of such reduced materials.

Based on this state of the art, the purpose of the present work was to understand the eventual role of the porous network in promoting the catalytic performances in CSDRM by comparing a non-porous and two mesoporous (obtained either by direct synthesis or by impregnation) alumina-based catalysts with same $\mathrm{Ni}$ content (5 wt\%). As far as we know, even though $\mathrm{Ni}$ on alumina catalysts have been widely studied (Table 1 ), structured alumina was never investigated as support of $\mathrm{Ni}$ in combined methane reforming. Our goal when applying different preparation methods was also to identify the effect of the syntheses conditions towards stability of the metallic nickel nanoparticles dispersed over (or in) the alumina support. Two methods were thus applied: postimpregnation by the two-solvents technique ${ }^{22}$ and a direct synthesis approach expected to favor the formation of strong $\mathrm{Ni}$ alumina interaction ${ }^{20}$ in principle favorable to $\mathrm{Ni}$ stabilization during combined reforming. ${ }^{7 e}$ A special attention was addressed as well to the fine characterization of the reduced materials (active form for the reaction). To understand the impact of the support on the physicochemical properties and on their consequences on catalysis, we also tested two silica supports, for comparison: an ordered mesoporous SBA-15 (prepared by typical sol-gel method) ${ }^{23}$ and a natural, low-cost, and widely available, macroporous diatomite (CeliteS). The selection of these supports was based on our recent results $^{18(a, b), 21}$ showing promising catalytic behaviors in DRM for both $\mathrm{Ni} / \mathrm{SBA}-15$ and $\mathrm{Ni} /$ diatoms catalysts.

\section{Experimental}

\subsection{Catalysts preparation}

Syntheses of "one-pot" alumina-based materials: The mesoporous nickel containing alumina was prepared via "one-pot" evaporationinduced self-assembly (EISA) method by fine control of the evaporation process, based on literature reported previously. ${ }^{20}$ The amount of $\mathrm{Ni}$ was fixed at $5 \mathrm{wt} \%$ as for all $\mathrm{Ni}$-containing samples investigated in this study. The synthesis procedure consisted in dissolving $1.0 \mathrm{~g}$ of $(\mathrm{EO})_{20}(\mathrm{PO})_{70}(\mathrm{EO})_{20}$ triblock copolymer (Pluronic $P 123, M_{n}=5800$, Sigma Aldrich, 43546-5) at room temperature (RT) in $20 \mathrm{ml}$ absolute ethanol under vigorous stirring, mixing it with 1.6 $\mathrm{ml}$ of $65.0 \mathrm{wt} \%$ nitric acid $\left(\mathrm{HNO}_{3}\right.$, Johnson Matthey S.A., extra pure), then adding simultaneously into the stirred solution $1.94 \mathrm{~g}$ of aluminium isopropoxide $\left(\mathrm{Al}\left(\mathrm{OPr}^{\mathrm{i}}\right)_{3} 98+\%\right.$, Sigma Aldrich, 220418) and $1.02 \mathrm{~g}$ of nickel nitrate hexahydrate $\left(\mathrm{Ni}\left(\mathrm{NO}_{3}\right)_{2} \cdot 6 \mathrm{H}_{2} \mathrm{O}\right.$, Sigma Aldrich, 13478-007); this corresponds to a total ( $\mathrm{Al}+\mathrm{Ni}$ ) molar composition of $10 \mathrm{mmol}$. This final mixture was covered with a polyethylene (PE) film, continuously stirred at RT for at least 7 hours until complete dissolution, and finally transferred into a beaker placed in a digital auto-regulator water-bath (Stuart SWB6D) set at $60^{\circ} \mathrm{C}$ to undergo the slow evaporation process (ethanol, acid) for 48 hours straight. The obtained light green xerogel (due to the presence of tetrahedral $\mathrm{Ni}^{2+}$ ions) was calcined slowly in air at $600^{\circ} \mathrm{C}$ for 5 hours (heating rate $0.5^{\circ} \mathrm{C} \cdot \mathrm{min}^{-1}$ ) to give the $\mathrm{Ni}_{5 \%} \mathrm{Al}_{2} \mathrm{O}_{3}$ (meso) sample. The exact same procedure applied without addition of nickel precursor (but increasing the amount of aluminium isopropoxide to $10 \mathrm{mmol}$ to keep constant overall concentrations) led to mesoporous $\mathrm{Al}_{2} \mathrm{O}_{3}$ (meso) (used below as support). In addition, a non-porous reference sample, labeled $\mathrm{Ni}_{5 \%} \mathrm{Al}_{2} \mathrm{O}_{3}(\mathrm{np})$, was synthesized by following the above described methodology but in absence of the structuring (BASF P123) agent.

Preparation of silica supports: The mesoporous SBA-15 silica support was synthesized according to a standard procedure described by Zhao et al. ${ }^{23 a}$ A double jacketed beaker of $2 \mathrm{~L}$ with an integrated stirring rod was used to obtain a homogenous texture, despite the large batch size. The batch was prepared using $60 \mathrm{~g}$ of

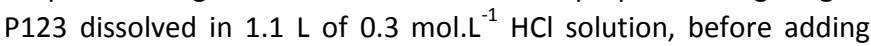
drop-by-drop $129 \mathrm{~g}$ of tetraethyl orthosilicate (TEOS $98+\%$, Sigma Aldrich, 13190-3) as silica source. Stirring was stopped just after TEOS addition, as recommended to favor the formation of isolated silica grains. ${ }^{23 b}$ After 24 hours at $35^{\circ} \mathrm{C}$, the hybrid product (solid and synthesis liquor) was introduced inside a stainless steel autoclave with an internal cover of Teflon and kept at $130^{\circ} \mathrm{C}$ for 24 hours. The solid fraction was next isolated by filtration on paper, washed with distilled water $(6 \mathrm{~L})$, then calcined in air (thin bed) at $500^{\circ} \mathrm{C}$ for 9 
hours (heating rate $2^{\circ} \mathrm{C} \mathrm{min}^{-1}$ ) to liberate the pores from the $\mathrm{P} 123$ template and to thus give sample SBA-15. For comparison purpose, a commercial diatomite natural silica sample, called CeliteS (Sigma Aldrich, 61790-532), was also used as support.

Preparation of impregnated samples: Impregnation of nickel was carried out on the $\mathrm{Al}_{2} \mathrm{O}_{3}$ (meso), SBA-15 and CeliteS supports using the "two solvents" loading method detailed elsewhere ${ }^{22}$ : briefly, $1 \mathrm{~g}$ of each type of support was suspended in $35 \mathrm{ml}$ of cyclohexane $\left(\mathrm{C}_{6} \mathrm{H}_{12}\right.$, Sigma Aldrich, 17919-1) under stirring for 2-3 minutes. Then $0.7 \mathrm{ml}$ of an aqueous nickel solution containing $0.05 \mathrm{~g}$ of $\mathrm{Ni}$ was added dropwise, using $\mathrm{Ni}\left(\mathrm{NO}_{3}\right)_{2} \cdot 6 \mathrm{H}_{2} \mathrm{O}$ as nickel precursor. The suspension was left to dry at RT (cyclohexane and water evaporation) before undergoing calcination in air (thin bed) at $450^{\circ} \mathrm{C}$ for 5 hours (heating rate $0.5^{\circ} \mathrm{C} \cdot \mathrm{min}^{-1}$ ) for removal of the adsorbed nitrates by oxidative desorption. The resulting samples are designated as $\mathrm{Ni}_{5 \%} \mathrm{Al}_{2} \mathrm{O}_{3}$ (imp), $\mathrm{Ni}_{5 \%} \mathrm{SBA}-15$ (imp) and $\mathrm{Ni}_{5 \%}$ CeliteS(imp), respectively.

\subsection{Catalysts characterizations}

$\mathrm{N}_{2}$ adsorption-desorption isotherms were obtained at $-196^{\circ} \mathrm{C}$ on a Micromeritics ASAP 2020 instrument. Prior to measurement, the samples $(40 \mathrm{mg}$ ) were degassed under vacuum for 3 hours at $\mathrm{T}=$ $300^{\circ} \mathrm{C}$. The Brunauer-Emmett-Teller (BET) surface areas were calculated from $B E T$ equation for a relative pressure $\left(P / P_{0}\right)$ range between 0.05 and 0.25 . The single point pore volume was calculated from the adsorption isotherm at a relative pressure of 0.990 , pore size distribution was calculated using the BarrettJoyner-Halenda (BJH) method for the adsorption branch of the isotherm, otherwise clearly specified.

Powder X-ray diffraction (XRD) measurements were performed on a PANalytical XPert ${ }^{3}$ diffractometer using $\mathrm{Cu}$ K $\alpha$ radiation $(\lambda=1.5405$ $\mathrm{nm}$ ) at RT from $2 \Theta$ of 20.0 to $90.0^{\circ}$ (WAXS for wide angle X-ray scattering). The measurements were conducted at a voltage of 30 $\mathrm{kV}$, the current was set at $10 \mathrm{~mA}$ and the step size was $0.02^{\circ}$. Crystalline phase identification was based on comparison with standard powder XRD files published by the international center for diffraction data (ICDD). Coherent domain sizes were calculated using the Scherrer equation: $D_{(h k)}=(K \lambda / \beta \cos \Theta)$, where $K=0.9$ is the shape factor for spherical particles, $\lambda$ is the $\mathrm{X}$-ray wavelength $(\lambda=$ $1.5405 \mathrm{~nm}$ for $\mathrm{Cu} \mathrm{K \alpha}$ ), 6 is the full width at half maximum (FWHM) of the diffraction peak and $\Theta$ is the peak position. The small angle $X$ Ray scattering (SAXS) measurements were recorded from $2 \Theta$ of 0.5 to $4.0^{\circ}$ (time per step: $1 \mathrm{~s}$ ) on a BRUKER type D8 ADVANCE diffractometer equipped with a $\mathrm{Cu} K \alpha$ irradiation source $(\lambda=1.5418$ $\mathrm{nm}$ ) and operating at $40 \mathrm{kV}$ and $30 \mathrm{~mA}$.

Temperature programmed reduction $\left(\mathrm{H}_{2}-\mathrm{TPR}\right)$ was performed on an Autochem 2920 unit, Micromeritics. The sample powder (100 mg) was loaded in a U-shaped quartz reactor and heated from RT up to $900^{\circ} \mathrm{C}$ at a rate of $7^{\circ} \mathrm{C} \cdot \mathrm{min}^{-1}$ under a 5 vol\% $\mathrm{H}_{2} / \mathrm{Ar}$ flow $\left(30 \mathrm{ml} \cdot \mathrm{min}^{-1}\right.$ ). The overall $\mathrm{H}_{2}$ consumption was constantly recorded by thermal conductivity detection (TCD). Before arrival to the detector, the gas flow was passed through a cold trap (made of ice and $\mathrm{NaCl}$ ) to remove any water generated during reduction and thus insure detection of the sole reduction process.

High-resolution transmission electron microscopy (HRTEM) images were taken on a JEOL-JEM 200 electron microscope operating at $200 \mathrm{KeV}$ ( $\mathrm{LaB}_{6}$ gun) and equipped with an energy dispersive spectroscopy (EDS) probe for local chemical analyses. In order to determine average particle sizes and compare them with the estimation based on XRD, the software "Comptage de Particules (LRS)" was used considering at least 500 particles for each sample.

TGA-DSC was performed to quantify carbon deposition amounts on the spent catalysts on a TA SDT Q600 thermal analyzer instrument from RT to $900^{\circ} \mathrm{C}$ (heating rate $10^{\circ} \mathrm{C} \cdot \mathrm{min}^{-1}$ ) in flowing air $\left(50 \mathrm{ml} \cdot \mathrm{min}^{-1}\right.$ ). The exhaust gas was analyzed by online gas spectrometry (MKS, ThermoSTAR) by following the masses $(\mathrm{m} / \mathrm{z})$ for $\mathrm{CO}(28)$ and $\mathrm{CO}_{2}(44)$.

\subsection{Reactivity measurements}

The catalytic test facility consisted of mass flow controllers, a water generator unit (Syringe pump, Teledyne ISCO, D-series, model 5000), a reactor unit (Microactivity, PID Eng and Tech) and a gas analysis unit (Inficon Micro-GC) equipped with a TCD and two columns in parallel for the detection of $\mathrm{CH}_{4}, \mathrm{CO}$ and $\mathrm{H}_{2}$ (molecular sieve column) and $\mathrm{CO}_{2}$ (plot $\mathrm{U}$ column). Catalytic reactions for combined steam and dry reforming of methane were conducted at atmospheric pressure $(\mathrm{P}=1 \mathrm{~atm})$ in a vertical fixed-bed continuous flow stainless steel (SS310) reactor. Prior to reaction, each sample (100mg, non-diluted, calcined form) was in-situ pre-treated (reduced) at $800^{\circ} \mathrm{C}$ for 3 hours under a flow $\left(30 \mathrm{ml}^{\left.-\mathrm{min}^{-1}\right)}\right.$ of 5 vol\% $\mathrm{H}_{2} / \mathrm{Ar}$. The flow was then switched to the reactants mixture $\mathrm{CH}_{4} / \mathrm{CO}_{2} / \mathrm{H}_{2} \mathrm{O} / \mathrm{Ar}=1 / 0.4 / 0.8 / 12$. This feed composition, with $\mathrm{CH}_{4} / \mathrm{CO}_{2}$ ratio (1/0.4) slightly different from the stoichiometric one $(1 / 033$, see CSDRM reaction detailed in section 1$)$, was chosen because it is best suited (due to side reactions) to produce a syngas with $\mathrm{H}_{2} / \mathrm{CO}$ ratio close to 2 , based on bibliography ${ }^{1 \mathrm{1}, 5 \mathrm{a}, 5 \mathrm{~b}, 5 \mathrm{c}}$ and on the HSC 7.1 simulation software $(\mathrm{H}, \mathrm{S}$ and $\mathrm{C}$ stand for enthalpy, entropy and heat capacity, respectively) used to calculate (i) thermodynamic conversion $\left(\mathrm{CH}_{4}\right.$ and $\left.\mathrm{CO}_{2}\right)$ levels and (ii) expected products $\left(\mathrm{H}_{2}\right.$ and $\left.\mathrm{CO}\right)$ contents at the applied conditions of temperature, pressure and composition (considering also dilution and carbon deposition). The gas hourly space velocity (GHSV) was

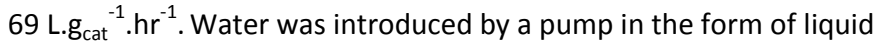
water $\left(0.005 \mathrm{ml} . \mathrm{min}^{-1}\right)$ that underwent evaporation $\left(6.15 \mathrm{ml} \cdot \mathrm{min}^{-1}\right)$ at $180^{\circ} \mathrm{C}$ (hotbox temperature) and was then mixed with the other gases and fed into the reactor. The reforming reaction was carried out at $800^{\circ} \mathrm{C}$ for $40 \mathrm{~h}$. The reaction temperature was controlled using a thermocouple placed in the middle of the reforming catalyst bed. The effluent was passed through a gas/liquid separator for condensing the residual steam before analyzing the gaseous mixture $\left(\mathrm{H}_{2}, \mathrm{CO}\right.$ products and unreacted $\mathrm{CH}_{4}$ and $\left.\mathrm{CO}_{2}\right)$ by Micro-GC. Catalytic measurements were repeated twice over each catalyst to check the reproducibility of the data. The conversion of $\mathrm{CH}_{4}\left(\mathrm{XCH}_{4}\right)$ and $\mathrm{CO}_{2}\left(\mathrm{XCO}_{2}\right)$ and the obtained syngas ratio $\left(\mathrm{H}_{2} / \mathrm{CO}\right)$ were calculated using Eqs. (1)-(3):

$$
\begin{aligned}
\mathrm{XCH}_{4}(\%) & =\frac{\left[\mathrm{CH}_{4}\right]_{\text {in }}-\left[\mathrm{CH}_{4}\right]_{\text {out }}}{\left[\mathrm{CH}_{4}\right]_{\text {in }}} \times 100 \\
\mathrm{XCO}_{2}(\%) & =\frac{\left[\mathrm{CO}_{2}\right]_{\text {in }}-\left[\mathrm{CO}_{2}\right]_{\text {out }}}{\left[\mathrm{CO}_{2}\right]_{\text {in }}} \times 100 \\
\frac{\mathrm{H}_{2}}{\mathrm{CO}} & =\frac{\text { mol of } \mathrm{H}_{2} \text { produced }}{\text { mol of CO produced }}
\end{aligned}
$$




\section{Results and discussion}

\subsection{Reducibility of the calcined Ni-based catalysts}

The overall experimental $\mathrm{H}_{2}$-uptake at $900^{\circ} \mathrm{C}$ (Table 2) was consistent with the complete reduction of the targeted amount of $\mathrm{Ni}$-species (circa $900 \mu \mathrm{mol} . \mathrm{g}^{-1}$ for $5 \mathrm{wt} \% \mathrm{Ni}$ ) over each of the studied samples. The types and relative abundances of reducible $\mathrm{Ni}$-species were directly correlated to their degree of interaction with the support as revealed form their reduction temperature on TPR profiles (Fig. 1).

\begin{tabular}{|c|c|c|c|}
\hline \multirow{2}{*}{$\begin{array}{l}\mathrm{SiO}_{2} \text {-based } \\
\text { samples }\end{array}$} & \multirow{2}{*}{$\begin{array}{l}\text { Total } \mathrm{H}_{2} \text { uptake } \\
\left(\mu \mathrm{mol} . \mathrm{g}^{-1}\right)\end{array}$} & \multicolumn{2}{|c|}{ Relative amount of $\mathrm{Ni}^{2+}$ species $^{[+]}(\%)$} \\
\hline & & $\mathrm{T}<450^{\circ} \mathrm{C}$ & $\mathrm{T}>450^{\circ} \mathrm{C}$ \\
\hline $\mathrm{Ni}_{5 \%}$ CeliteS(imp) & 940 & 49 & 51 \\
\hline $\mathrm{Ni}_{5 \%} \mathrm{SBA}-15(\mathrm{imp})$ & 892 & 30 & 70 \\
\hline $\begin{array}{l}\mathrm{Al}_{2} \mathrm{O}_{3} \text {-based } \\
\text { samples }\end{array}$ & $\begin{array}{l}\text { Total } \mathrm{H}_{2} \text { uptake } \\
\left(\mu \mathrm{mol} . \mathrm{g}^{-1}\right)\end{array}$ & $\mathrm{T}<500^{\circ} \mathrm{C}$ & $\mathrm{T}>500^{\circ} \mathrm{C}$ \\
\hline $\mathrm{Ni}_{5 \%} \mathrm{Al}_{2} \mathrm{O}_{3}(\mathrm{np})$ & 958 & 78 & 22 \\
\hline $\mathrm{Ni}_{5} \% \mathrm{Al}_{2} \mathrm{O}_{3}(\mathrm{imp})$ & 901 & 20 & 80 \\
\hline $\mathrm{Ni}_{5 \%} \mathrm{Al}_{2} \mathrm{O}_{3}$ (meso) & 941 & 3 & 97 \\
\hline
\end{tabular}

Concerning the Ni-based silica samples, two types of species were distinguished: (i) those undergoing reduction within a temperature range below $450^{\circ} \mathrm{C}$, attributable to easily reducible free $\mathrm{NiO}$ and (ii) $\mathrm{Ni}$ species with enhanced interaction with silica, reduced at higher temperatures, typically above $450^{\circ} \mathrm{C}^{24}$ For $\mathrm{Ni}_{5 \%}$ CeliteS(imp) (Fig. $1 \mathrm{~A}$, profile (a)), $\mathrm{Ni}$ tended to be equally distributed (Table 2) between the two categories. With $\mathrm{Ni}_{5 \%} \mathrm{SBA}-15$ (imp) (Fig. $1 \mathrm{~A}$, profile (b)), the dominant contribution corresponded to species with enhanced interaction with silica. This difference might be the result of different availabilities in $\mathrm{SiO}_{2}$ surface sites, related to the distinct surface areas and pore volumes between both silica supports (as introduced in section 3.3): indeed, the smaller available surfaces on Celites would limit the formation of mixed phases during the impregnation steps. ${ }^{25}$

A similar reducibility classification could be adopted for nickel on alumina-based samples, with characteristic temperature ranges depending upon the interaction between nickel and alumina. $\mathrm{Ni}_{5 \%} \mathrm{Al}_{2} \mathrm{O}_{3}$ (np) (Fig. $1 \mathrm{~B}$, profile (c)) presented peaks at $\mathrm{T}>600^{\circ} \mathrm{C}$, attributed to the reduction of nickel strongly interacting with the support, better described as nickel-aluminate spinel phases. The peaks centered at $\mathrm{T}<600^{\circ} \mathrm{C}$ (starting above $500^{\circ} \mathrm{C}$, Fig. 1B) were mainly assigned to free and easily reducible $\mathrm{NiO}$ particles having low MSI. ${ }^{26}$ Based on quantifications (Table 2), it is clear that the non-porous sample housed notably higher amounts of free $\mathrm{NiO}$ species compared to impregnated $\mathrm{Ni}_{5 \%} \mathrm{Al}_{2} \mathrm{O}_{3}$ (imp) (Fig. 1B, profile (d)) and to "one-pot" $\mathrm{Ni}_{5 \%} \mathrm{Al}_{2} \mathrm{O}_{3}$ (meso) (Fig. 1B, profile (e)). Interestingly, $\mathrm{Ni}_{5 \%} \mathrm{Al}_{2} \mathrm{O}_{3}$ (meso) displayed peaks located generally at temperatures higher than $600^{\circ} \mathrm{C}$ suggesting that all Ni-species are in strong interacting with the structured alumina matrix. This is in agreement with previous results obtained by $\mathrm{Xu}$ et al. ${ }^{18 \mathrm{e}}$ reporting absence of dissociated or of free nickel oxides having no interaction with the support. Similarly, Morris et al. ${ }^{20 a}$ studied the solid state ${ }^{27} \mathrm{Al}$ MAS NMR (nuclear magnetic resonance spectroscopy) spectra of mesoporous "one-pot" $\mathrm{Ni}-\mathrm{Al}_{2} \mathrm{O}_{3}$ samples and deduced that nickel atoms, deposited in the course of alumina precipitation, replaced tetrahedrally coordinated aluminum atoms generating, as a

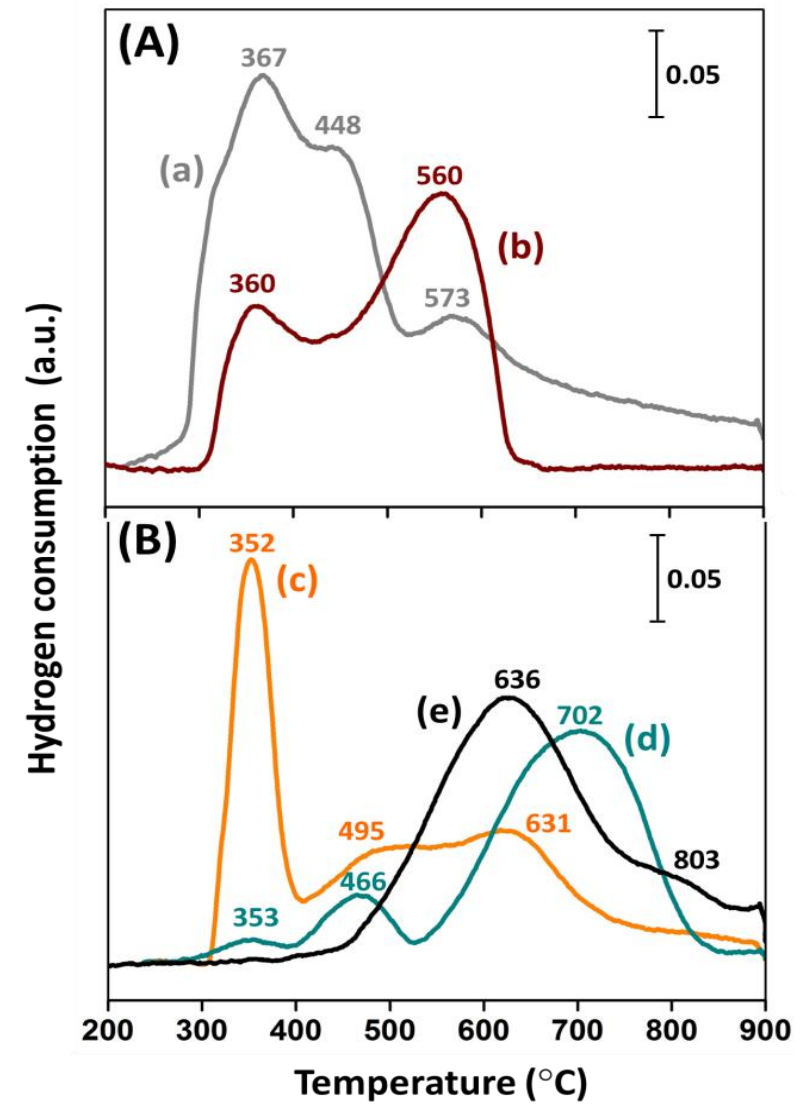

Fig. $1 \mathrm{H}_{2}$-TPR profiles of (A) calcined silica-based samples: (a) $\mathrm{Ni}_{5 \%}$ CeliteS(imp), (b) $\mathrm{Ni}_{5 \%} \mathrm{SBA}-15$ (imp) and (B) calcined alumina-based samples: (c) $\mathrm{Ni}_{5 \%} \mathrm{Al}_{2} \mathrm{O}_{3}$ (np), (d) $\mathrm{Ni}_{5 \%} \mathrm{Al}_{2} \mathrm{O}_{3}$ (imp) and (e) $\mathrm{Ni}_{5 \%} \mathrm{Al}_{2} \mathrm{O}_{3}$ (meso).

consequence, solid solutions of $\mathrm{Ni}$ inside alumina in the form of $\mathrm{Ni}$ $\mathrm{O}-\mathrm{Al}$ structures. Hence, the relatively high reduction temperature of the "one-pot" $\mathrm{Ni}_{5 \%} \mathrm{Al}_{2} \mathrm{O}_{3}$ (meso) sample originated from $\mathrm{Ni}$ species characterized by strong MSI. As for impregnated $\mathrm{Ni}_{5 \%} \mathrm{Al}_{2} \mathrm{O}_{3}(\mathrm{imp})$, the route of its preparation generated both types of species ( $\mathrm{Ni}$ aluminates and free $\mathrm{NiO}$ species). With respect to the slight temperature differences observed for the main peaks between the two samples, it should be recalled that TPR is carried out in dynamic conditions, far from equilibrium, which potentially affects the overall reduction signature depending on the size and location of the species involved. The importance of establishing strong MSI between $\mathrm{Ni}$ and alumina is expected to inhibit sintering of metallic particles whereas $\mathrm{NiO}$ species, with weaker interaction with $\mathrm{Al}_{2} \mathrm{O}_{3}$, should present a greater tendency to deactivate by sintering as was recently demonstrated by Fang et al. ${ }^{18 \mathrm{~d}}$ in DRM conditions.

\subsection{Catalytic reactivity in combined reforming of methane}

Before catalytic tests, the calcined samples were in-situ reduced to generate the metallic $\mathrm{Ni}^{0}$ particles required for the reaction. Catalytic performances in terms of reactivity and selectivity as a function of test duration are displayed in Fig. 2.

Under our reaction conditions $\left(\mathrm{CH}_{4} / \mathrm{CO}_{2}\right.$ molar ratio of $\left.1 / 0.4\right)$ and based on thermodynamic calculations, a higher $\mathrm{CH}_{4}$ conversion (by almost $6 \%$ ) should be a priori expected compared to that of $\mathrm{CO}_{2}$. For both silica-based catalysts, the initial $\mathrm{CO}_{2}$ conversion largely exceeds, on the contrary, that of $\mathrm{CH}_{4}$ (curves $(a, b)$, Fig. 2(A,B)), suggesting strong occurrence of the reverse water gas shift (RWGS, 

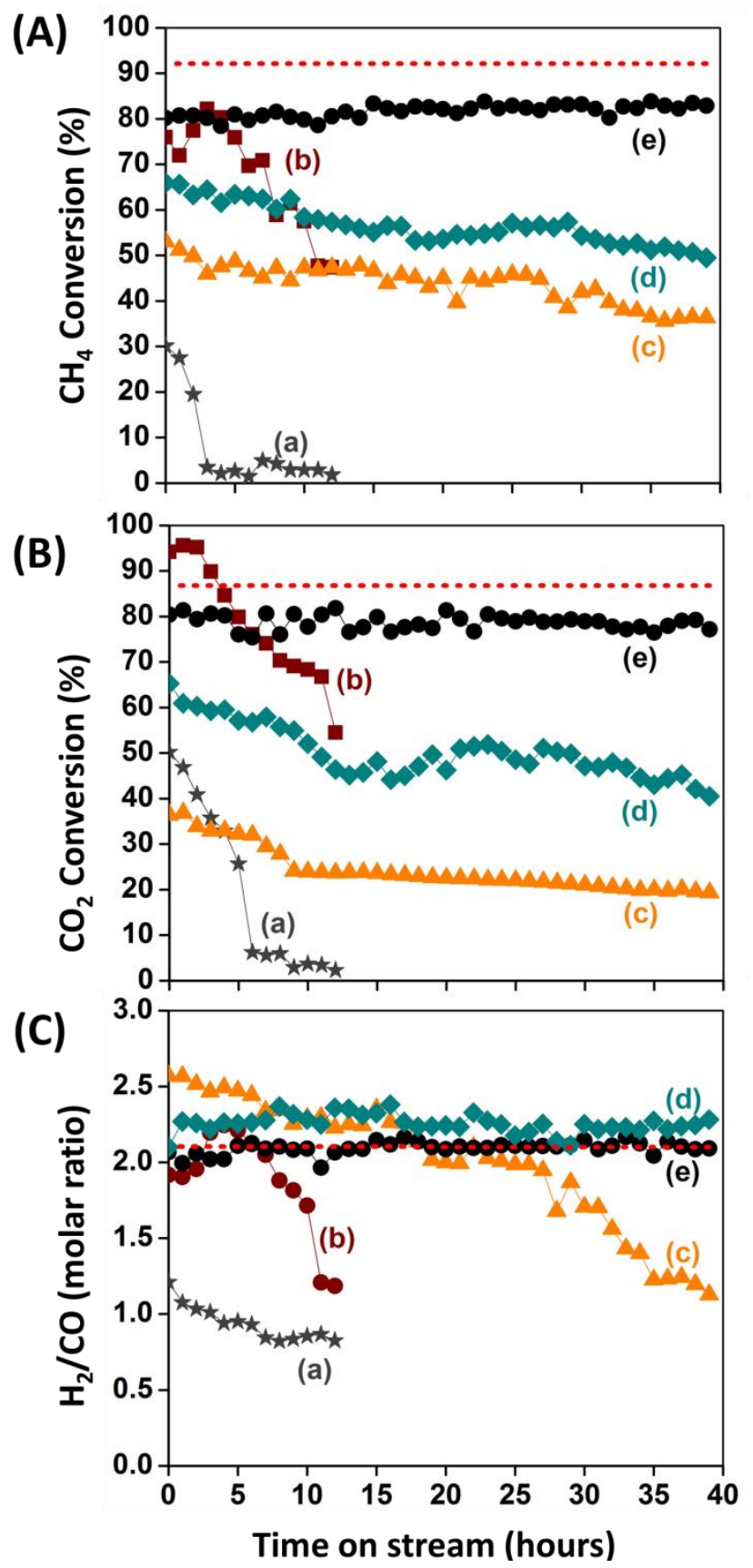

Fig. 2 (A) $\mathrm{CH}_{4}$ and (B) $\mathrm{CO}_{2}$ conversions and (C) molar $\mathrm{H}_{2} / \mathrm{CO}$ product ratio during combined methane reforming $\left(\mathrm{T}=800^{\circ} \mathrm{C}\right.$ and $\left.\mathrm{P}=1 \mathrm{~atm}\right)$ over in situ reduced (a) $\mathrm{Ni}_{5 \%}$ CeliteS(imp), (b) $\mathrm{Ni}_{5 \%} \mathrm{SBA}-15$ (imp), (c) $\mathrm{Ni}_{5 \%} \mathrm{Al}_{2} \mathrm{O}_{3}$ (np), (d) $\mathrm{Ni}_{5 \%} \mathrm{Al}_{2} \mathrm{O}_{3}$ (imp) and (e) $\mathrm{Ni}_{5 \%} \mathrm{Al}_{2} \mathrm{O}_{3}$ (meso). Thermodynamic values (pointedlines) are calculated with the HSC 7.1 software.

$\mathrm{CO}_{2}+\mathrm{H}_{2} \rightarrow \mathrm{H}_{2} \mathrm{O}+\mathrm{CO}$ ) side-reaction. This agrees with the low $\mathrm{H}_{2} / \mathrm{CO}$ product ratios (curves (a,b), Fig. $2 \mathrm{C}$ ) compared to the expected one for CSDRM. Conversions on both catalysts continuously decrease with time on stream (being however significantly higher on $\mathrm{Ni}_{5 \%}$ SBA-15(imp)) and the $\mathrm{H}_{2} / \mathrm{CO}$ ratios drop down to values close to 1 indicating that simultaneous dry and steam reforming reactions are no longer taking place. Instead, strong deactivation occurs, due to reoxidation of metallic nickel nanoparticles as will be deduced later on from spent catalysts characterizations (section 3.5).
In the alumina-based catalysts family, $\mathrm{Ni}_{5 \%} \mathrm{Al}_{2} \mathrm{O}_{3}(\mathrm{np})$ suffers since the very beginning from rapid deactivation with respect to both $\mathrm{CH}_{4}$ and $\mathrm{CO}_{2}$ conversions (curves (c), Fig. 2(A,B)), along with a severe decline in the molar product ratio from 2.5 to 1.1 (curve (c), Fig. $2 \mathrm{C}$ ). The initial $\mathrm{H}_{2} / \mathrm{CO}$ ratio was similarly slightly

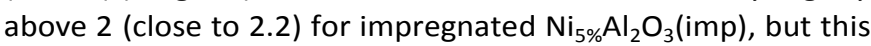
value remained at this level even during progressive deactivation on stream (curves (d), Fig. 2A-C). Also, slight fluctuations (both in $\mathrm{H}_{2} / \mathrm{CO}$ ratios and in $\mathrm{CO}_{2}$ conversions) along with $\mathrm{CH}_{4}$ conversions higher than $\mathrm{CO}_{2}$ ones by more than $6 \%$ were seen, possibly indicating an imbalance in the combined reaction with SRM occurring preferentially with respect to DRM. ${ }^{7 f, 7 h, 15 b}$ The higher $\mathrm{CH}_{4}$ than $\mathrm{CO}_{2}$ conversion could also be due to methane decomposition to $C(s)$, but the former assumption is most likely since low amounts of carbon were observed over these 2 samples (see section 3.5). Concerning the $\mathrm{Ni}_{5 \%} \mathrm{Al}_{2} \mathrm{O}_{3}$ (meso) catalyst (curves (e), Fig. $2 \mathrm{~A}-\mathrm{C}$ ), it maintained the most active, stable and selective behaviour, with moreover reactivity values close to the maximum expected ones with respect to thermodynamic equilibrium data (red-pointed lines).

Thus the performances of the "one-pot" $\mathrm{Ni}_{5 \%} \mathrm{Al}_{2} \mathrm{O}_{3}$ (meso) catalyst appear highly promising, and this stands also when compared to bibliographic performances obtained by other teams over alumina based-catalysts, even at higher $\mathrm{Ni}$ loadings. It is worth recalling that deactivation is commonly reported for nickel alumina-based catalysts (Table 1) and extensive studies continue to be carried out to overcome the drawbacks of coking and $\mathrm{Ni}$ sintering generally encountered on conventional alumina supports. For instance, basic hydrotalcite ${ }^{5 a}$ or mixed $\mathrm{CeO}_{2}-\mathrm{ZrO}_{2}{ }^{\text {7b }}$ oxides were proposed as more suitable than alumina for nickel species dispersion. Moreover, addition of promoters having basic $(\mathrm{MgO})^{7 \mathrm{cc} 7 \mathrm{~g}}$ or redox $\left(\mathrm{CeO}_{2}\right)^{7 \mathrm{~d}}$ properties on $\mathrm{Ni} / \mathrm{Al}_{2} \mathrm{O}_{3}$ catalysts was proved to be beneficial towards coking and sintering limitations (by enhancing MSI). Additionally, García-Diéguez et al. ${ }^{7 f}$ used a nano-fibrous high surface area alumina to improve $\mathrm{Ni}$ dispersion and found high initial $\mathrm{CH}_{4}$ conversion but low $\mathrm{CO}_{2}$ conversion and consequently a $\mathrm{H}_{2} / \mathrm{CO}$ ratio far from 2 (Table 1 ) even after doping with $\mathrm{Rh}(0.04 \mathrm{wt} \%)$. Similarly, Kang et al. ${ }^{\mathrm{7g}}$ proceeded towards the protection of nickel particles from agglomeration and coking by synthesizing a core-shell sample with $\mathrm{Ni}^{0}$ nanoparticles coated by $\mathrm{Al}_{2} \mathrm{O}_{3}$. Their $10 \mathrm{wt} \% \mathrm{Ni} / \mathrm{Al}_{2} \mathrm{O}_{3}$ catalyst exhibited high and stable $\mathrm{CH}_{4}$ conversion but low $\mathrm{CO}_{2}$ conversion as well as low selectivity with respect to metgas production (Table 1), due to SRM dominance relatively to DRM and to decay in the reactions leading to $\mathrm{CO}$ formation. Finally, Son et al. $^{7 e}$ developed a stable and selective $7 \mathrm{wt} \% \mathrm{Ni} / \mathrm{Al}_{2} \mathrm{O}_{3}$ catalyst by $\mathrm{Ni}$ impregnation on a commercial $\mathrm{Al}_{2} \mathrm{O}_{3}$ support but its preparation required extensive pot-synthesis treatments. Therefore, the above "one-pot" $\mathrm{Ni}_{5 \%} \mathrm{Al}_{2} \mathrm{O}_{3}$ (meso) catalyst, obtained by direct (one-step) synthesis and by using a monometallic standard type of support (alumina), represents a highly effective candidate for CSDRM, offering the advantage of avoiding post-synthesis treatments and secondary metals (eventually expensive) incorporation. 


\subsection{Structure and porosity of calcined and reduced samples}

The textural and structural properties of the calcined and of the reduced (similar reduction treatment as before reaction) samples were evaluated by SAXS analysis (Fig. $3(A, B)$ ) and $N_{2}$ adsorption measurements (Table 3, Fig. 3(C,D)).

For all SBA-15 based-samples, a well-resolved high intensity (100) peak accompanied with two tiny (110) and (200) peaks were seen, all characteristic of an highly ordered hexagonal p6mm mesoporous structure: ${ }^{2 a}$ the network of the parent SBA-15 support (pattern c, Fig. 3A) was thus preserved after impregnation followed by calcination (pattern d, Fig. 3A) as well as after high temperature reduction (pattern d', Fig. 3A). Some collapse (lower peaks intensities) and some pore shrinking (regular shift to higher angles) were however noted along successive thermal treatments as also confirmed below based on $\mathrm{N}_{2}$ sorption data. Concerning the diatomite family (patterns $\left(a, b, b^{\prime}\right)$, Fig. $3 A$ ) no evidence of any ordered-porosity was detected, even over the (Ni free) CeliteS support.

Concerning the mesoporous alumina family (Fig. 3B), a diffraction peak at circa $0.94^{\circ}$ and a weak one at circa $1.5^{\circ}$, respectively ascribed to the (100) and (110) plane reflections of a well-ordered alumina based-mesostructure, ${ }^{20}$ were systematically visible, with however a slight intensity decrease when going from ( $\mathrm{Ni}$ free) $\mathrm{Al}_{2} \mathrm{O}_{3}$ (meso) (pattern a) to calcined (pattern d) then reduced (pattern d') $\mathrm{Ni}_{5 \%} \mathrm{Al}_{2} \mathrm{O}_{3}$ (meso). These observations indicate that the $\mathrm{Ni}$ incorporation in the synthesis medium did not strongly affect the 2D hexagonal alumina structure (p6mm symmetry) and that the "one-pot" ordered nickel alumina sample had a very good thermal stability (even under high temperature reduction). In this series of samples, a shift of the main peak also detected between ( $\mathrm{Ni}$ free) $\mathrm{Al}_{2} \mathrm{O}_{3}$ (meso) and $\mathrm{Ni}_{5 \%} \mathrm{Al}_{2} \mathrm{O}_{3}$ (meso) suggests a slightly higher pore opening in the $\mathrm{Ni}$ containing sample, as will be indeed confirmed latter on. Contrarily, diffraction peaks were no longer detected for impregnated $\mathrm{Ni}_{5 \%} \mathrm{Al}_{2} \mathrm{O}_{3}(\mathrm{imp})$ (patterns $\left(c, c^{\prime}\right)$, Figs. $\left.3 \mathrm{~B}\right)$ implying that the long-range ordered mesopores of the parent $\mathrm{Al}_{2} \mathrm{O}_{3}$ (meso) support had been blocked (partially damaged) during the impregnation process. Finally, $\mathrm{Ni}_{5 \%} \mathrm{Al}_{2} \mathrm{O}_{3}(n p)$ presented no SAXS peaks (patterns $\left(a, a^{\prime}\right)$, Fig. $3 B$ ) in line with the absence of structuring agent in its course of synthesis.

Complementary to SAXS, $\mathrm{N}_{2}$-sorption analysis demonstrated typical type IV isotherms with $\mathrm{H}_{1}$-type hysteresis loops, reflected by the appearance of capillary condensation steps at $P / P_{O}=0.6-0.8$ for the parent SBA-15 and $\mathrm{Al}_{2} \mathrm{O}_{3}$ (meso) supports (curves (c,a), Figs. $3(\mathrm{C}, \mathrm{D})$, respectively) and for the $\mathrm{Ni}_{5 \%} \mathrm{SBA}-15$
(A)

(B)
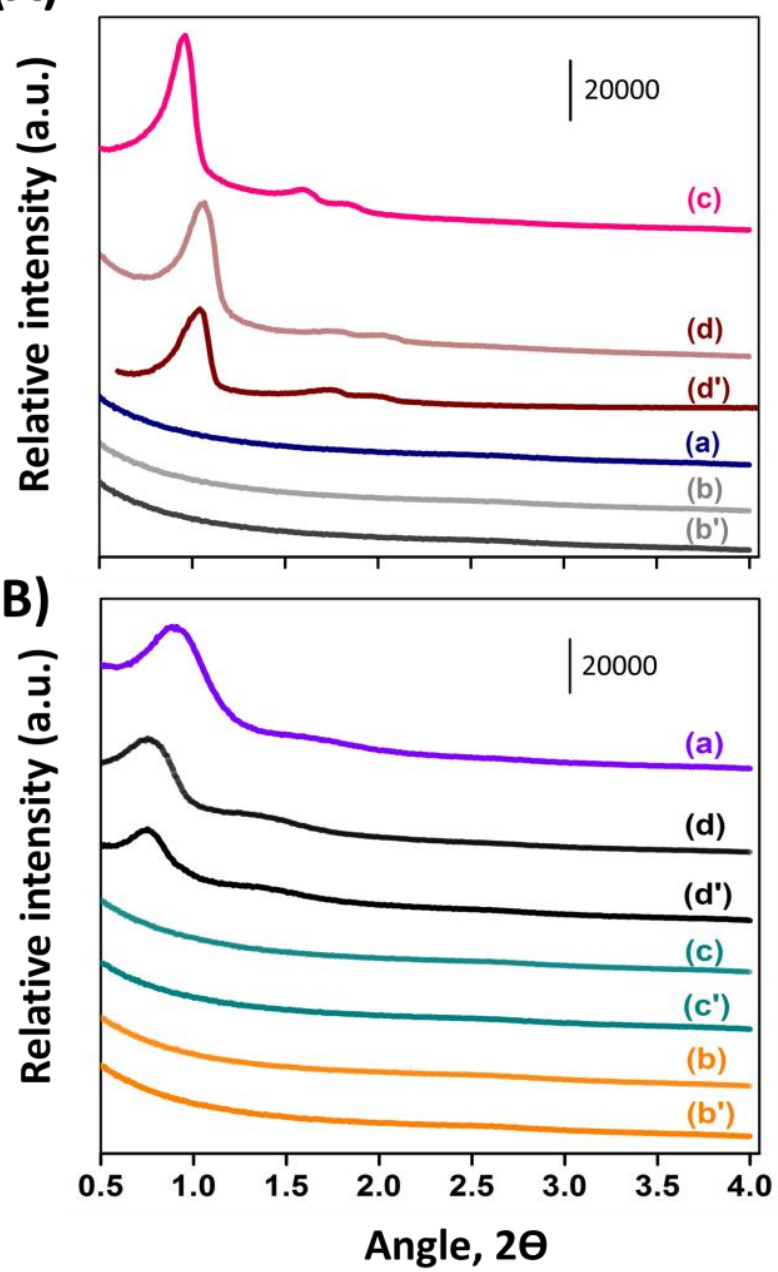

(C)

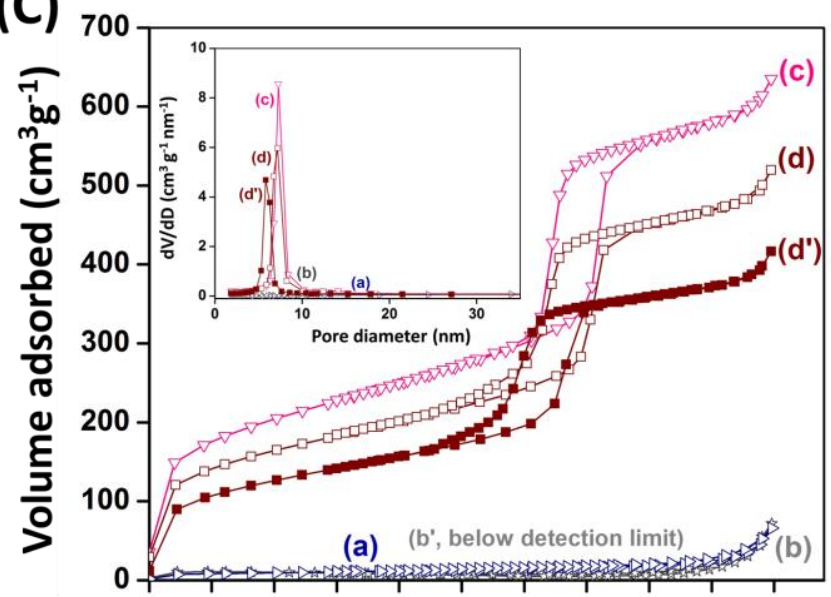

(D)

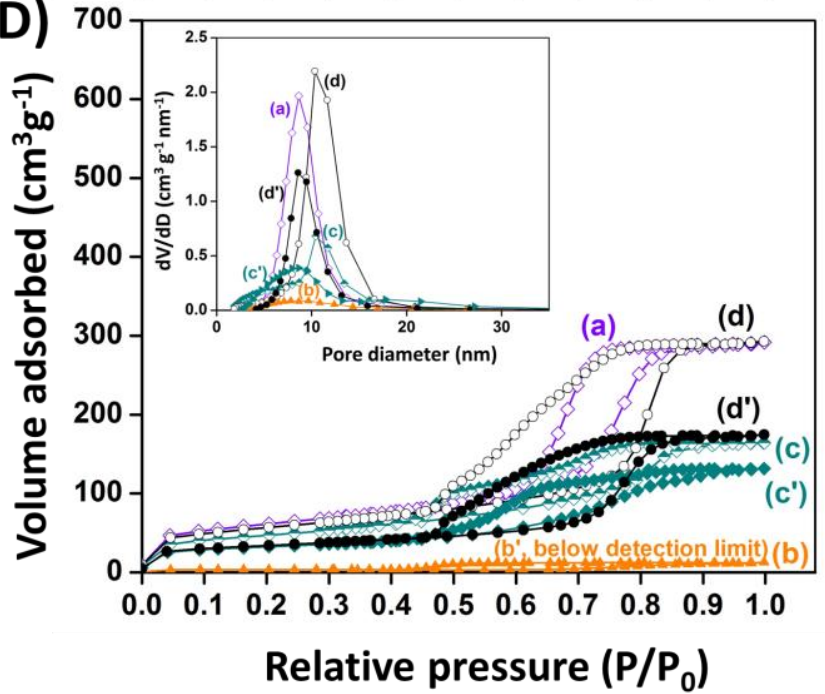

Fig. $3(A, B)$ SAXS patterns and (C,D) $N_{2}$ adsorption-desorption isotherms and pore size distributions (inset figures) of calcined (a-d) and reduced ( $b^{\prime}, d^{\prime}$ ),

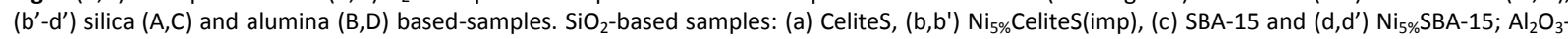
based samples: (a) $\mathrm{Al}_{2} \mathrm{O}_{3}$ (meso), (b,b') $\mathrm{Ni}_{5 \%} \mathrm{Al}_{2} \mathrm{O}_{3}(\mathrm{np})$, (c, c') $\mathrm{Ni}_{5 \%} \mathrm{Al}_{2} \mathrm{O}_{3}(\mathrm{imp})$ and (d, d') $\mathrm{Ni}_{5}{ } \mathrm{Al}_{2} \mathrm{O}_{3}$ (meso). For XRD patterns, an offset was applied along Yaxis for the sake of clarity. 


\begin{tabular}{|c|c|c|c|}
\hline Samples & $\begin{array}{c}\text { BET specific surface } \\
\text { area }\left(m^{2} \cdot \mathrm{g}^{-1}\right)\end{array}$ & $\begin{array}{c}\text { Pore volume } \\
\left(\mathrm{mL} \cdot \mathrm{g}^{-1}\right)\end{array}$ & $\begin{array}{l}\text { Average pore } \\
\text { diameter }(n m)\end{array}$ \\
\hline \multicolumn{4}{|l|}{ Calcined } \\
\hline Celites & 30 & 0.11 & --- \\
\hline $\mathrm{Ni}_{5 \%}$ Celites(imp) & 21 & 0.09 & --- \\
\hline SBA-15 & 672 & 0.87 & 7 \\
\hline $\mathrm{Ni}_{5 \%} \mathrm{SBA}-15$ (imp) & 540 & 0.72 & 6.5 \\
\hline $\mathrm{Al}_{2} \mathrm{O}_{3}$ (meso) & 225 & 0.46 & 8.4 \\
\hline $\mathrm{Ni}_{5 \%} \mathrm{Al}_{2} \mathrm{O}_{3}(\mathrm{np})$ & 18 & 0.02 & --- \\
\hline $\mathrm{Ni}_{5 \%} \mathrm{Al}_{2} \mathrm{O}_{3}(\mathrm{imp})$ & 170 & 0.31 & 6.8 \\
\hline $\mathrm{Ni}_{5 \%} \mathrm{Al}_{2} \mathrm{O}_{3}$ (meso) & 215 & 0.45 & 9.5 \\
\hline \multicolumn{4}{|c|}{ In-situ reduced $\left(\mathrm{H}_{2}\right)$} \\
\hline $\mathrm{Ni}_{5 \%}$ Celites(imp) & --- & --- & --- \\
\hline $\mathrm{Ni}_{5 \%} \mathrm{SBA}-15$ (imp) & 424 & 0.61 & 6.2 \\
\hline $\mathrm{Ni}_{5 \%} \mathrm{Al}_{2} \mathrm{O}_{3}(\mathrm{np})$ & --- & --- & --- \\
\hline $\mathrm{Ni}_{5 \%} \mathrm{Al}_{2} \mathrm{O}_{3}(\mathrm{imp})$ & 104 & 0.21 & 7.7 \\
\hline $\mathrm{Ni}_{5}{ } \mathrm{Al}_{2} \mathrm{O}_{3}$ (meso) & 111 & 0.33 & 9.0 \\
\hline
\end{tabular}

below the limit of detection (BET surface are $<10 \mathrm{~m}^{2} . \mathrm{g}^{-1}$ ) after reduction (Table 3 , related inset figures).

Compared to their calcined forms, all reduced $\mathrm{Ni}_{5 \%} \mathrm{SBA}$ 15(imp), $\mathrm{Ni}_{5 \%} \mathrm{Al}_{2} \mathrm{O}_{3}$ (meso) and $\mathrm{Ni}_{5 \%} \mathrm{Al}_{2} \mathrm{O}_{3}$ (imp) exhibited smaller specific surface areas and pore volumes (Table 3 ), mainly attributable to thermal contraction and/or condensation by dehydration and dehydroxylation during high temperature $\left(800^{\circ} \mathrm{C}\right)$ treatment of either silica or alumina frameworks. ${ }^{29}$ In addition to structural transitions, easily detectable for alumina based-samples (wide-angle X-ray diffraction, see section 3.4), particles migration to the external surface and/or agglomeration with consecutive pores plugging could be another a reason for such porosity loss.

Furthermore, in line with partial shrinkage of the alumina skeleton, an increase and a widening in the average pore diamter (6.8 to $7.7 \mathrm{~nm}$ ) were observed for reduced $\mathrm{Ni}_{5 \%} \mathrm{Al}_{2} \mathrm{O}_{3}$ (imp) (Table 3). Nevertheless, such shrinkage was not observed for "one-pot" $\mathrm{Ni}_{5 \%} \mathrm{Al}_{2} \mathrm{O}_{3}$ (meso) which PSD remained narrow, as for $\mathrm{Ni}_{5 \%} \mathrm{SBA}-15$ (imp), both being in the same range as for their calcined versions, (inset curves $\left(b^{\prime}, c^{\prime}\right)$, Figs. $3(C, D)$, respectively). The quite well (even if partially) preserved uniform structure of reduced $\mathrm{Ni}_{5 \%} \mathrm{Al}_{2} \mathrm{O}_{3}$ (imp), verified as well by SAXS, emphasizes the potential application of this mesoporous catalysts in the high temperature reforming reaction.

\section{respectively).}

Their pore size distributions PSD (inset figures and Table 3) were quite sharp and uniformly located within the conventional range of mesopores with textural values (Table 3 ) in accordance with previous studies on similar materials. ${ }^{18 a, 18 c}$ Yet, the larger pore diameter of $\mathrm{Ni}_{5 \%} \mathrm{Al}_{2} \mathrm{O}_{3}$ (meso) (calcined form) compared to that of nickel free $\mathrm{Al}_{2} \mathrm{O}_{3}$ (meso) (Table 3) follows a trend similar to that already reported by Morris et al. $^{20 a}$ It can be the result of nickel incorporation into the mesoporous alumina structure, probably in the form of $\mathrm{Ni}-\mathrm{O}$ $\mathrm{Al}^{27}$ (in line with the TPR analysis).

Moreover, it is worth noting that the desorption branch of the "one-pot" sample was typical of "ink-bottle" interconnected pores with different size distributions of cavities and necks ${ }^{28}$ (corresponding PSD, not shown, revealing 3 categories of pores at circa 6.6, 4.4 and a narrow one at $3.4 \mathrm{~nm}$ ). On the other hand, the condensation steps for impregnated $\mathrm{Ni}_{5 \%} \mathrm{SBA}$ 15(imp) and $\mathrm{Ni}_{5 \%} \mathrm{Al}_{2} \mathrm{O}_{3}(\mathrm{imp})$ samples (curves (d,c) Figs. 3(C,D), respectively) shifted to lower $P / P_{O}$ values along with a decrease in pore volumes and pore diameters compared to their respective SBA-15 and $\mathrm{Al}_{2} \mathrm{O}_{3}$ (meso) supports (Table 3 ). This behaviour is typical of partial plugging and of a restricted access to mesopores, supporting the presence, after impregnation then calcination treatments, of oxide nanoparticles inside the pores. Nevertheless, $\mathrm{Al}_{2} \mathrm{O}_{3}$ (meso) presented a higher structural sensibility to post-impregnation than SBA-15: it indeed suffered from almost 32 and 19\% losses of porous volume and average pore diameter, respectively, compared to only 17 and 7\% for SBA-15 (Table 3). Thus, in agreement with SAXS observations, a potential damage was encountered upon impregnation in the case of ordered alumina whereas the SBA-15 maintained a perfectly structured porous system.

With respect to CeliteS, $\mathrm{Ni}_{5 \%}$ CeliteS(imp) (curves (a,b), Fig. $3 \mathrm{~A}$ ) and $\mathrm{Ni}_{5 \%} \mathrm{Al}_{2} \mathrm{O}_{3}(\mathrm{np})$ (curve b, Fig. $3 \mathrm{~B}$ ) materials, all displayed an increase in adsorbed $\mathrm{N}_{2}$ only at high relative pressures $\left(P / P_{O}\right.$ 0.7-0.95), typical of non-ordered macroporous systems with insignificant pore volumes and wide PSD. The signal became

\subsection{Structure, size and location of supported nanoparticles}

Structural information on the deposited metal species in calcined, reduced and spent catalysts was gained from wide-angle $\mathrm{X}$-ray diffraction. The patterns are presented in Figs. 4 and 5 for $\mathrm{SiO}_{2}$ and $\mathrm{Al}_{2} \mathrm{O}_{3}$-based samples, respectively. Accordingly, the estimated particle sizes of the $\mathrm{Ni}$ species at the various successive stages of samples preparation are listed in Table 4.

\begin{tabular}{|c|c|c|c|c|c|}
\hline \multirow{3}{*}{$\begin{array}{l}\mathrm{SiO}_{2} \text {-based } \\
\text { catalysts }\end{array}$} & \multirow{2}{*}{$\begin{array}{c}\text { Calcined } \\
\varnothing \mathrm{NiO}(\mathrm{nm})\end{array}$} & \multicolumn{2}{|c|}{ Reduced } & \multicolumn{2}{|c|}{ Spent } \\
\hline & & \multicolumn{2}{|c|}{$\varnothing \mathrm{Ni}^{0}(\mathrm{~nm})$} & \multicolumn{2}{|c|}{$\begin{array}{c}\varnothing \mathrm{Ni}_{(\mathrm{nm})}^{0} \varnothing \mathrm{NiO} \\
\end{array}$} \\
\hline & $\mathrm{XRD}$ & $\mathrm{XRD}^{\#}$ & TEM & $\mathrm{XRD}^{\#}$ & TEM \\
\hline $\mathrm{Ni}_{5 \%}$ CeliteS(imp) & 7 & 22 & 23 & n.d.* & 36 \\
\hline $\mathrm{Ni}_{5 \%} \mathrm{SBA}-15(\mathrm{imp})$ & 9 & 11 & 11 & n.d.* & 18 \\
\hline \multirow{2}{*}{$\begin{array}{l}\mathrm{Al}_{2} \mathrm{O}_{3} \text {-based } \\
\text { catalysts }\end{array}$} & $\varnothing \mathrm{NiO}(\mathrm{nm})$ & \multicolumn{2}{|c|}{$\varnothing \mathrm{Ni}^{0}(\mathrm{~nm})$} & \multicolumn{2}{|c|}{$\varnothing \mathrm{Ni}^{0}(\mathrm{~nm})$} \\
\hline & XRD & $\mathrm{XRD}^{\#}$ & TEM & $\mathrm{XRD}^{\#}$ & TEM \\
\hline $\mathrm{Ni}_{5 \%} \mathrm{Al}_{2} \mathrm{O}_{3}(\mathrm{np})$ & 14 & 22 & 25 & 48 & 50 \\
\hline $\mathrm{Ni}_{5 \%} \mathrm{Al}_{2} \mathrm{O}_{3}(\mathrm{imp})$ & n.d. & 10 & 9.5 & 18 & 19 \\
\hline $\mathrm{Ni}_{5 \%} \mathrm{Al}_{2} \mathrm{O}_{3}$ (meso) & n.d. & n.d. & 3.0 & n.d. & 5.5 \\
\hline \multicolumn{6}{|c|}{$\begin{array}{l}\text { \# Calculated using Scherrer's equation at } 2 \mathrm{O}=51.8^{\circ},[200] \text { indexed plane } \\
\text { n.d.: not determined, n.d. }{ }^{*} \text { : not determined due to overlapping between } \mathrm{Ni}^{0} \text { and } \\
\text { NiO peaks, both present on spent samples. }\end{array}$} \\
\hline
\end{tabular}

The silica supports (patterns (a,c), Fig. 4A) with amorphous $\mathrm{SiO}_{2}$ walls gave a broad signal centered at about $22^{\circ}$, with additional peaks of crystallized silica cristobalite (ICDD file \# 85-0462) in the case of natural diatomite. The additional peaks visible for reduced $\mathrm{Ni}_{5 \%} \mathrm{SBA}-15$ (imp) and $\mathrm{Ni}_{5 \%}$ CeliteS(imp) (patterns (b,d), Fig. 4B) are all characteristics of metallic $\mathrm{Ni}^{0}$ with face centered cubic (FCC) unit cell (ICDD file \# 65-0380). The globally higher peak intensity along with smaller broadening for the Ni diatomite sample reveals the formation 


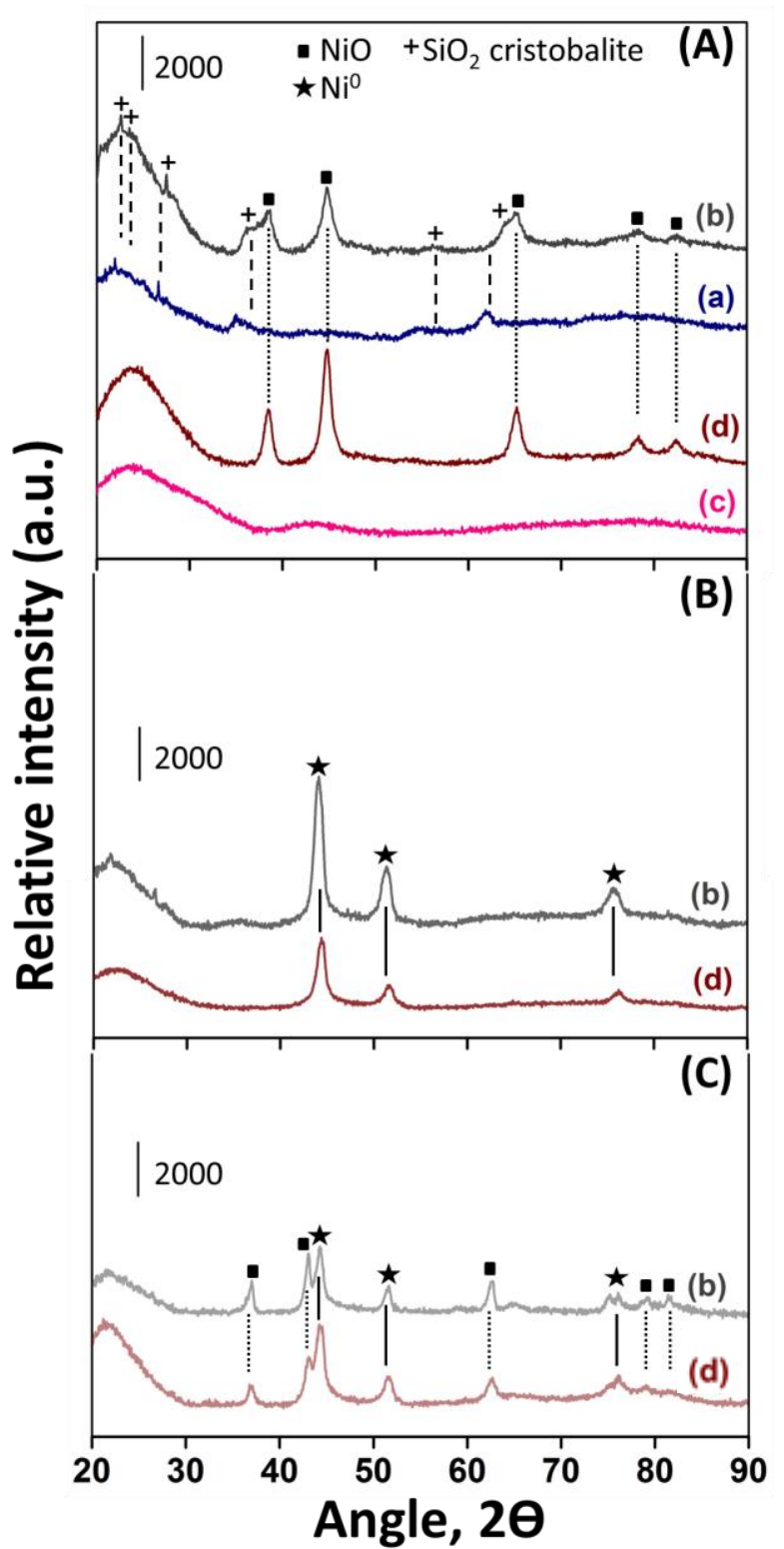

Fig. 4 Wide-angle XRD patterns of (A) calcined, (B) reduced and (C) spent samples: (a) CeliteS, (b) $\mathrm{Ni}_{5 \%}$ CeliteS(imp), (c) SBA-15 and (d) Ni ${ }_{5 \%} \mathrm{SBA}-15$. An offset was applied along $\mathrm{Y}$-axis for the sake of clarity.

of significantly larger $\mathrm{Ni}^{0}$ nanoparticles on the marcoporous compared to mesoporous silica support (Table 4). This is confirmed as well by TEM images showing evidence of big particles in reduced $\mathrm{Ni}_{5 \%}$ CeliteS(imp), assembled heterogeneously on the external surface of the macroporous spherules (pores with average openings around $100 \mathrm{~nm}$, Fig. $6 \mathrm{~A})$, while the $\mathrm{Ni}$ species appear smaller and better dispersed in reduced $\mathrm{Ni}_{5 \%} \mathrm{SBA}-15$ (imp) (occluded in the ordered channels, Fig. 6B, Table 4) even if few large Ni species are also present on the outside of the silica grains (black dots on the external surface). Such distribution between internal and external nanoparticles suggests that some species might have migrated from the channels to the surface during calcination and/or have sintered during harsh reduction treatments. ${ }^{30}$

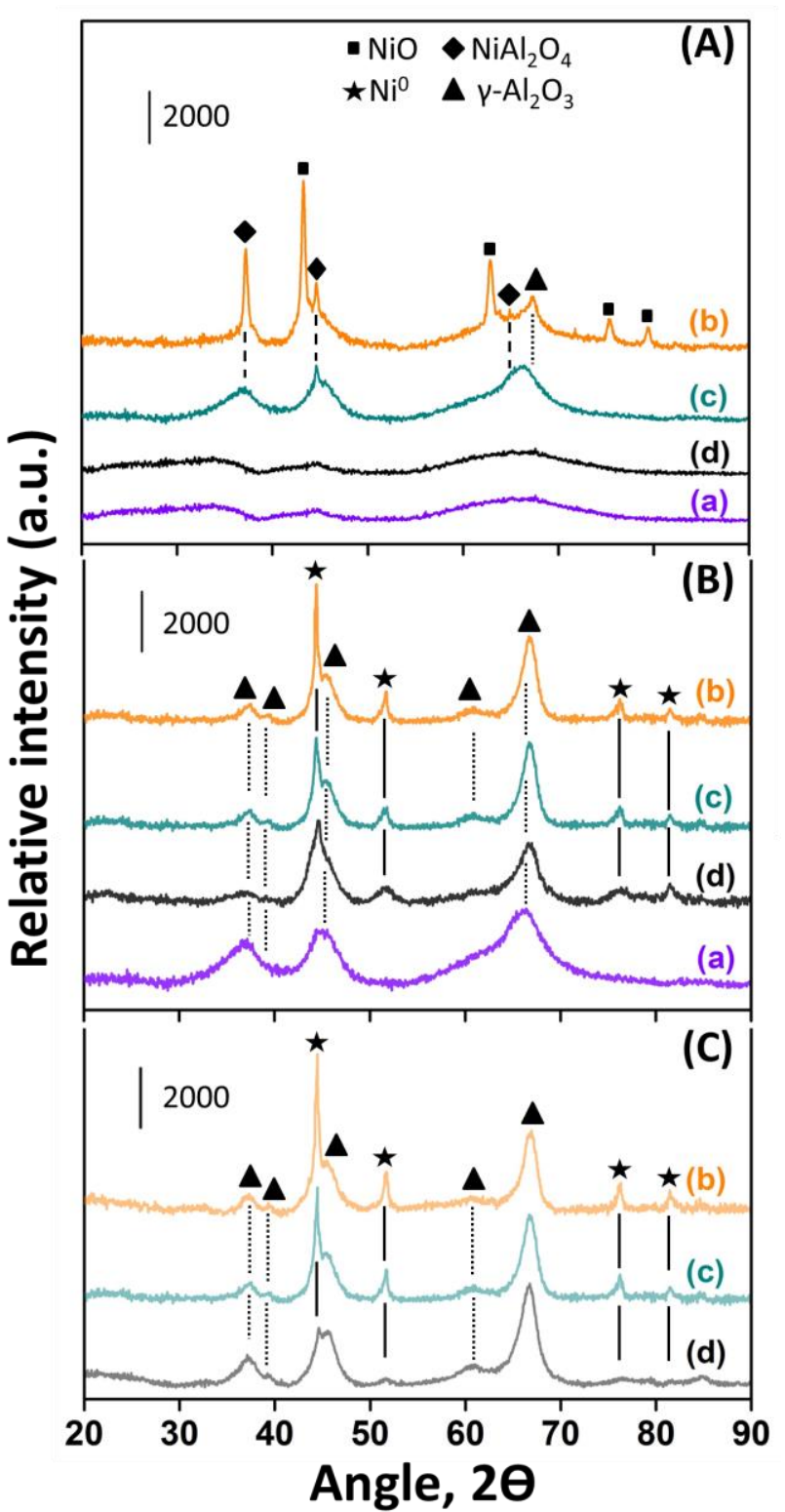

Fig. 5 Wide-angle XRD patterns of (A) calcined, (B) reduced and (C) spent samples: (a) $\mathrm{Al}_{2} \mathrm{O}_{3}$ (meso), (b) $\mathrm{Ni}_{5 \%} \mathrm{Al}_{2} \mathrm{O}_{3}$ (np), (c) $\mathrm{Ni}_{5 \%} \mathrm{Al}_{2} \mathrm{O}_{3}$ (imp) and (d) $\mathrm{Ni}_{5 \%} \mathrm{Al}_{2} \mathrm{O}_{3}$ (meso). An offset was applied along $\mathrm{Y}$-axis for the sake of clarity.

The relatively enhanced dispersion over SBA-15 was verified as well by local EDS analysis performed over several grains for a given sample. Indeed, the local atomic $\mathrm{Ni} / \mathrm{Si}$ ratios in $\mathrm{Ni}$ containing zones were quite heterogeneous (between 0.03 and 0.06) in $\mathrm{Ni}_{5 \%}$ CeliteS(imp) compared to rather homogeneous (in the range of 0.07-0.09) in $\mathrm{Ni}_{5 \%} \mathrm{SBA}-15$ (imp); note that the lower values on the macroporous diatomite supported sample fully agree with the presence of very big isolated non-supported external $\mathrm{Ni}$ particles (observable by SEM analysis), ${ }^{21}$ not counted during such EDS analysis of individual diatomite grains. Accordingly, the initial higher catalytic reactivity of $\mathrm{Ni}_{5 \%} \mathrm{SBA}-15$ (imp) compared to $\mathrm{Ni}_{5 \%}$ CeliteS(imp) (Fig. 2) could be directly associated to the smaller and easily accessible metallic centers preserved within 

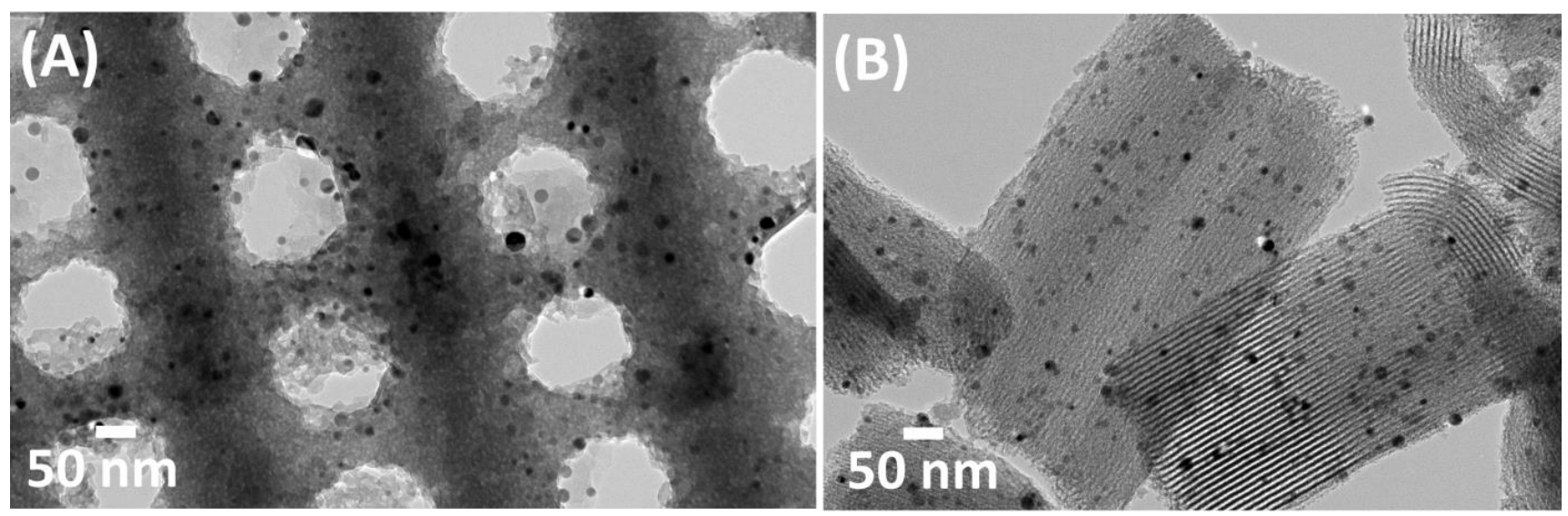

Fig. 6 Representative TEM micrographs of the in-situ reduced $\left(800^{\circ} \mathrm{C} / 3 \mathrm{~h}\right.$ ) catalysts: (A) Ni $\mathrm{i}_{\%} \mathrm{CeliteS}(\mathrm{imp})$ and (B) $\mathrm{Ni}{ }_{5 \%} \mathrm{SBA}-15$ (imp)

the pores of structured SBA-15 compared to the sintered-ones over macroporous Celites.

Concerning the alumina based-materials, the synthesis method was demonstrated to have a crucial influence on the textural properties (as observed by SAXS and $\mathrm{N}_{2}$-sorption) and this also stands regarding the dispersion and location of the $\mathrm{Ni}$ species. It is of special interest to note the absence of $\mathrm{NiO}$ diffraction peaks for "one-pot" prepared $\mathrm{Ni}_{5 \%} \mathrm{Al}_{2} \mathrm{O}_{3}$ (meso) (pattern d, Fig. $5 \mathrm{~A})$, attesting a very high $\mathrm{Ni}$-species dispersion within the mesoporous alumina framework. The diffraction pattern was in fact quite similar to that of ( $\mathrm{Ni}$ free) $\mathrm{Al}_{2} \mathrm{O}_{3}$ (meso) (pattern a,
Fig. 5A), showing only weak signals coming from the amorphous walls of the ordered mesoporous alumina. For both $\mathrm{Ni}$-free and $\mathrm{Ni}$-containing one-pot mesoporous materials, a phase transition to crystalline $\mathrm{Al}_{2} \mathrm{O}_{3} \gamma$-phase (ICDD file \# 100425) was observed after reduction at $800^{\circ} \mathrm{C}$ (patterns (a,d), Fig. 5B) along with the apperance, for reduced $\mathrm{Ni}_{5 \%} \mathrm{Al}_{2} \mathrm{O}_{3}$ (meso), of tiny and broad $\mathrm{Ni}^{0}$ diffraction peaks (indexed as on the pattern) indicating some sintering, although very limited, and thus an effective stabilization of the Ni species.

Consistently, the preserved dispersion was confirmed by TEM/EDS
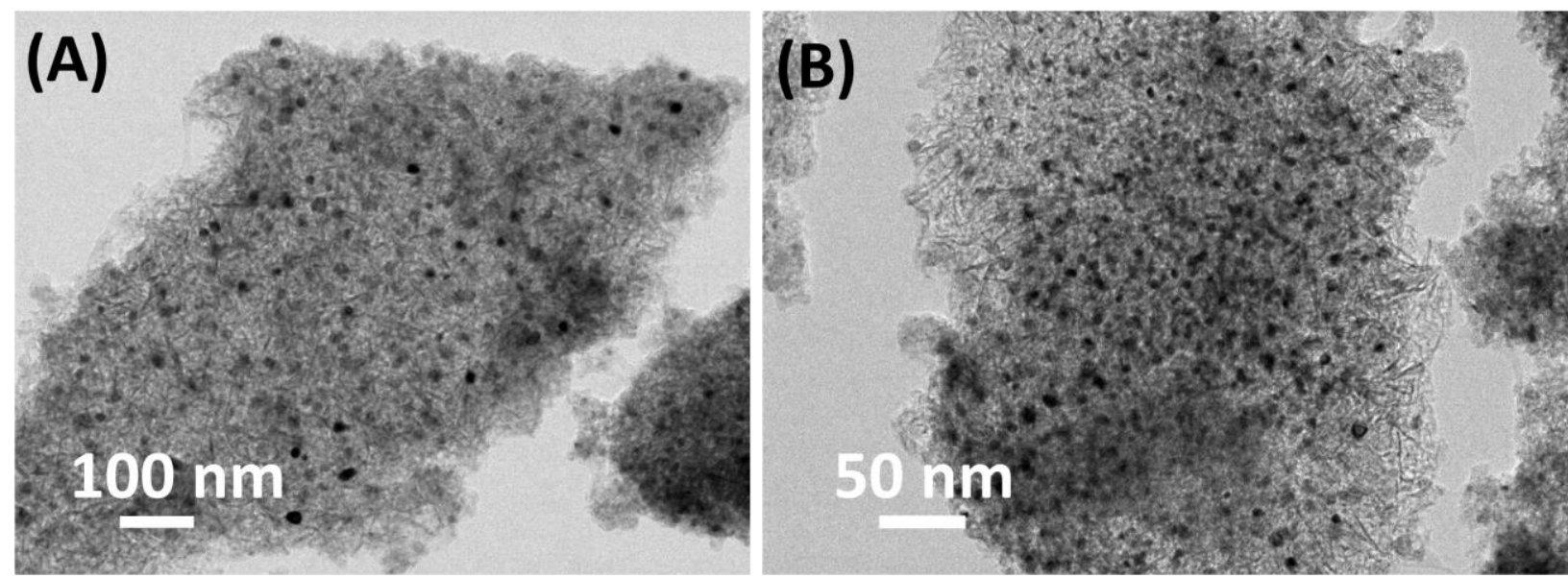

\section{(C)}

\section{$100 \mathrm{~nm}$}

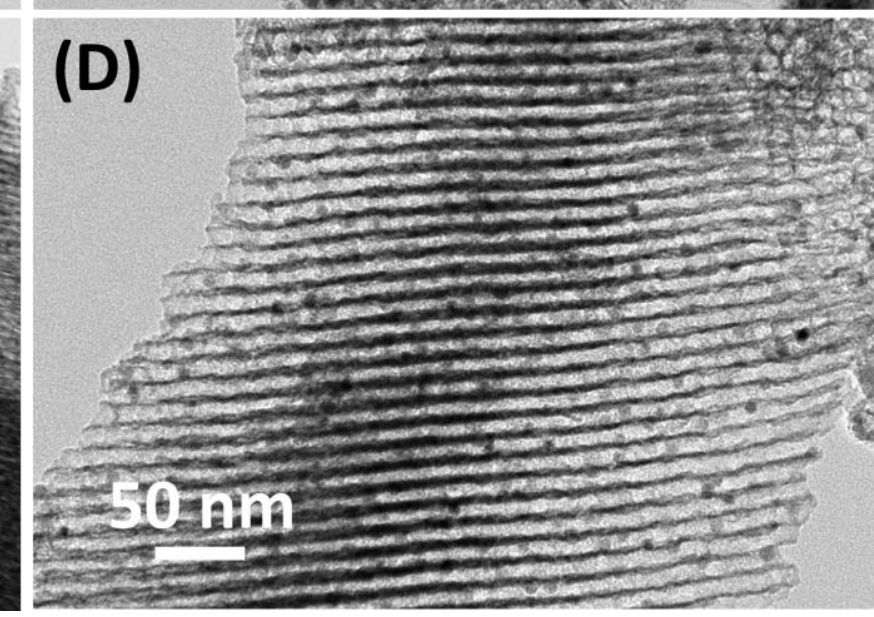

Fig. 7 Representative TEM micrographs of the in-situ reduced $\left(800^{\circ} \mathrm{C} / 3 \mathrm{~h}\right.$ ) catalysts: $(\mathrm{A}, \mathrm{B}) \mathrm{Ni}_{5 \%} \mathrm{Al}_{2} \mathrm{O}_{3}(\mathrm{imp})$ and $(\mathrm{C}, \mathrm{D}) \mathrm{Ni}_{5 \%} \mathrm{Al}_{2} \mathrm{O}_{3}($ meso) . 
observations (Figs. 7C,D) that revealed an average $\mathrm{Ni}^{0}$ particle size of approximately $3 \mathrm{~nm}$ (Table 4 ) and $\mathrm{Ni} / \mathrm{Al}$ atomic ratios around 0.09 over all of the considered grains zones. All of the population of nanoparticles (appearing as very small dark spots on the grey alumina matrix) was visibly homogeneously located inside the regular hexagonal arrangement of the porous structure (Figs. 7C,D). On the contrary, $\mathrm{Ni}_{5 \%} \mathrm{Al}_{2} \mathrm{O}_{3}(\mathrm{np})$ (calcined form) displayed intense $\gamma$ $\mathrm{Al}_{2} \mathrm{O}_{3}$ peaks together with peaks of spinel $\mathrm{Ni}$-aluminate phase (pattern (b), Fig. 5A) as well as apparent and measurable (Table 4) NiO diffraction peaks (FCC, ICDD file \# 089-7130), consistent with the poor $\mathrm{Ni}$ dispersion expected on such non-porous support. A spinel phase was also detected, although to a much lower extent, in impregnated $\mathrm{Ni}_{5 \%} \mathrm{Al}_{2} \mathrm{O}_{3}(\mathrm{imp}$ ) (pattern b, Fig. $5 \mathrm{~A}$ ) where neither $\mathrm{NiO}$ nor alumina $\mathrm{X}$-ray diffraction peaks were found, illustrating again the easier metal dispersion on a mesoporous support. It is worth adding that the spinel $\mathrm{Ni}$-aluminate phase was not detected for mesoporous "one-pot" $\mathrm{Ni}_{5 \%} \mathrm{Al}_{2} \mathrm{O}_{3}$ (meso) (pattern (d), Fig. $5 \mathrm{~A}$ ) although high TPR reduction temperatures (pattern (e), Fig. 1B) revealed predominant presence of $\mathrm{Ni}-\mathrm{O}-\mathrm{Al}$ species in this sample. This suggests a highly dispersed (or amorphous) state of such species in the walls of the mesoporous $\mathrm{Ni}_{5} \mathrm{Al}_{2} \mathrm{O}_{3}$ (meso) network. Upon heating $\mathrm{Ni}_{5 \%} \mathrm{Al}_{2} \mathrm{O}_{3}(\mathrm{np})$ and $\mathrm{Ni}_{5}{ } \mathrm{Al}_{2} \mathrm{O}_{3}(\mathrm{imp})$ in $\mathrm{H}_{2}$ at $800^{\circ} \mathrm{C}$, both types of nickel species (either free or present in spinel structures) were reduced to $\mathrm{Ni}^{0}$ (pattern (b,c), Fig. 5B), the obtained metallic nanoparticles being still smaller over the impregnated sample compared to the non-porous one (Table 4). In line with SAXS and $\mathrm{N}_{2}$-sorption, TEM images of reduced $\mathrm{Ni}_{5 \%} \mathrm{Al}_{2} \mathrm{O}_{3}$ (imp) (Figs. 7A,B) exhibited "sponge-like" (Fig. 7A) and in some regions "worm-like" appearances (Fig. 7B), with no evidence of pore arrangements within the structure. Such shape contrasts with the initial organized mesoporous network of the used $\mathrm{Al}_{2} \mathrm{O}_{3}$ (meso) support and reveals a partial structural damage during preparations steps (even when performed carefully), in line with above-mentioned drastic decrease of mean pores size (Table 3). Such type of damage, already reported for potassium-modified mesoporous alumina preparations, ${ }^{31}$ may result from a rather high sensitivity of the ordered alumina network (higher than for ordered silica) to the treatments carried out during preparation, namely impregnation (involving aqueous solution) and subsequent thermal oxidative treatment (removal by decomposition of the nitrates from the initial $\mathrm{Ni}$ precursor). In the structurally partially damaged $\mathrm{Ni}_{5 \%} \mathrm{Al}_{2} \mathrm{O}_{3}$ (imp) sample, the metallic nanoparticles appear randomly deposited ( $\mathrm{Ni} / \mathrm{Al}$ atomic ratios between 0.01-0.2) on the external surface (spherical dots, Figs. $7 \mathrm{~A}, \mathrm{~B}$ ), with an average particle size around $9 \mathrm{~nm}$ (calculated from both XRD and TEM). This value is three times higher than the $3 \mathrm{~nm}$ mentioned above for homogeneously dispersed $\mathrm{Ni}^{0}$ in "one-pot" $\mathrm{Ni}_{5 \%} \mathrm{Al}_{2} \mathrm{O}_{3}$ (meso), accentuating on the effectiveness of the "one-pot" synthesis approach compared to conventional impregnation.

From all above discussed data, it can be seen that the order of conversions on alumina-based catalysts $\left(\mathrm{Ni}_{5 \%} \mathrm{Al}_{2} \mathrm{O}_{3}\right.$ (meso)> $\mathrm{Ni}_{5 \%} \mathrm{Al}_{2} \mathrm{O}_{3}(\mathrm{imp})>\mathrm{Ni}_{5} \mathrm{Al}_{2} \mathrm{O}_{3}(\mathrm{np})$, Fig. 2) follows the same order as that of $\mathrm{Ni}^{0}$ dispersion (i.e. opposite to particle sizes order, Table 4). Even if expected, this observation strongly emphasizes the importance of ensuring high $\mathrm{Ni}$ dispersion through appropriate conditions of sample preparation and cataytic testing. Moreover, not only the conversions levels but also the selectivity varies with $\mathrm{Ni}$ dispersion: thus, all catalysts with poorly dispersed $\mathrm{Ni}\left(\mathrm{Ni}_{5 \%} \mathrm{Al}_{2} \mathrm{O}_{3}(\mathrm{np})\right.$ and $\left.\mathrm{Ni}_{5 \%} \mathrm{Al}_{2} \mathrm{O}_{3}(\mathrm{imp})\right)$ lead to $\mathrm{H}_{2} / \mathrm{CO}$ ratios above 2 at initial reaction stages (followed by a decrease down to 1 for the non-porous sample), whereas $\mathrm{Ni}_{5 \%} \mathrm{Al}_{2} \mathrm{O}_{3}$ (meso) with enhanced $\mathrm{Ni}$ dispersion yields the expected product ratio value of 2 . These observations demonstrate the occurrence of side-reactions on the poorly dispersed catalysts, such as steam and dry reforming (that both take place at high temperature), SRM occurring probably preferentially compared to DRM in view of the easier activation of $\mathrm{H}_{2} \mathrm{O}$ and $\mathrm{CH}_{4}$ compared to that of inert $\mathrm{CO}_{2}{ }^{15(b, e)}$. In contrast, combined methane reforming (the targeted reaction) takes place continuously on the highly dispersed, stable and selective mesoporous $\mathrm{Ni}_{5 \%} \mathrm{Al}_{2} \mathrm{O}_{3}$ (meso) catalyst.

\subsection{Deactivation analysis of the $\mathrm{SiO}_{2}$ and $\mathrm{Al}_{2} \mathrm{O}_{3}$-based catalysts}

Herein, the reacted (40h spent) catalysts were characterized by XRD, TEM and thermogravimetry to check further the deactivation causes.

The wide-angle XRD patterns showed the presence of both $\mathrm{Ni}^{0}$ (active phase) and $\mathrm{NiO}$ crystalline phases on the silica-based catalysts (Fig. 4C), revealing partial nickel in-situ reoxidation during CSDRM on both silica supports. For $\mathrm{Ni}_{5 \%}$ Celites, this is in
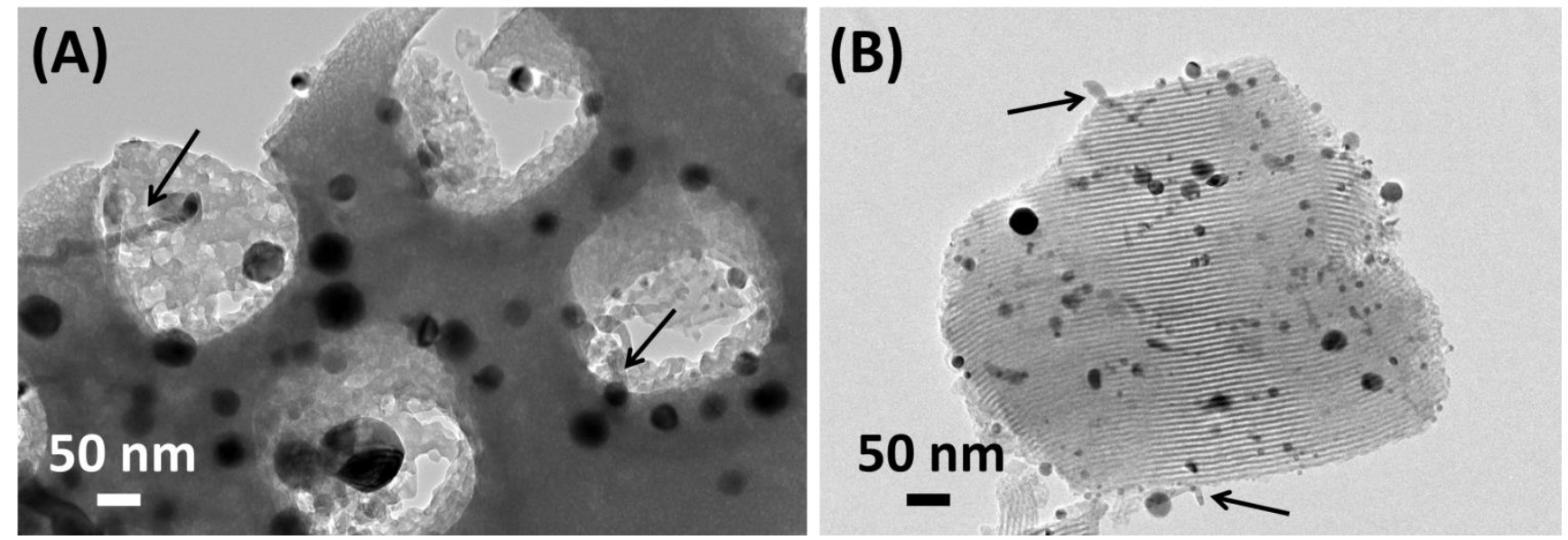

Fig. 8 Representative TEM micrographs of the spent $\left(800^{\circ} \mathrm{C} / 2 \mathrm{Oh}, \mathrm{CH}_{4} / \mathrm{CO}_{2} / \mathrm{H}_{2} \mathrm{O}=1 / 0.4 / 0.8 / 12\right)$ catalysts: (A) $\mathrm{Ni}_{5 \%} \mathrm{CeliteS}(\mathrm{imp})$ and (B) $\mathrm{Ni} \mathrm{i}_{5 \%} \mathrm{SBA}-15$ (imp). Carbon is marked with arrows. 
accordance with our recent DRM studies on $\mathrm{Ni}$ /diatoms carried out at $650^{\circ} \mathrm{C}^{21}$ Actually, these previous materials presented high sensibility to steam and were deactivated via reoxidation of $\mathrm{Ni}^{0}$ to $\mathrm{NiO}$ by water generated from the RWGS side-reaction. Such nickel reoxidation occurred also on $\mathrm{Ni}_{5 \%} \mathrm{SBA}-15$ (imp) during CSDRM, even though it was absent on similar Ni/SBA-15 after DRM reaction. ${ }^{18(a, b)}$ Such partial reoxidation on both silica-based catalysts having distinct $\mathrm{Ni}$ dispersion shows that reoxidation is not size dependent (Table 4). Very interestingly, and contrarily to spent silica catalysts, alumina-based ones presented solely $\mathrm{Ni}^{0}$ X-ray diffraction signatures (Fig. $5 \mathrm{C}$ ) indicating full preservation of the reduced nickel state after reaction. For both families of catalysts, no peaks corresponding to carbonaceous deposits were found, indicating either their presence in low amount (below detection limit) and/or their amorphous type. ${ }^{32}$

Typical TEM images of spent $\mathrm{Ni}_{5 \%}$ CeliteS(imp) (Fig. $8 \mathrm{~A}$ ) revealed extremely large $\mathrm{Ni}$ nanoparticles (difficult to distinguish whether $\mathrm{Ni}^{0}$ or $\mathrm{NiO}$ ), in accordance with the thin XRD peaks (pattern (b), Fig. 4C), and some carbon deposition (mainly in the form of short nanotubes with big metallic $\mathrm{Ni}^{0}$ tips, see arrows in Fig. $8 \mathrm{~A}$ ). In the case of $\mathrm{Ni}_{5 \%} \mathrm{SBA}-15$ (imp) (Fig. 8B), the hexagonal array of SBA-15 silica was still clearly visible and partially filled by nanoparticles, but agglomerated $\mathrm{Ni}$ species were also found on the external surface along with few very short nanotubes (arrows, Fig. 8B). Deactivation was therefore mainly associated with partial reoxidation (XRD data) and sintering (Table 4) rather than with coking.

$\mathrm{Ni}$ deactivation by reoxidation on silica supports, under similar reaction conditions in steam and at high temperature, was recently observed by Nieva et al. ${ }^{33 a}$ in parallel to much resistant $\mathrm{Ni}$ on $\mathrm{Al}_{2} \mathrm{O}_{3}$, $\mathrm{MgAl}_{2} \mathrm{O}_{4}$ or $\mathrm{ZnAl}_{2} \mathrm{O}_{4}$. Likewise, Matsumura et al. ${ }^{33 \mathrm{~b}}$ found that $\mathrm{Ni}$ on $\mathrm{Al}_{2} \mathrm{O}_{3}$ and $\mathrm{ZrO}_{2}$ catalysts were deactivated by carbon deposition without reoxidation whereas reoxidation occurred over silica-based catalyst. Moreover, deactivation was reported on core-shell Ni/SiO catalysts. ${ }^{33 \mathrm{C}}$ Also, partial nickel reoxidation of Ni/SBA-15 during SRM was deduced from XRD patterns of spent catalysts. ${ }^{33(\mathrm{~d}, \mathrm{e})}$ In CSDRM, one study (Table 1) dealing with $\mathrm{Ni} / \mathrm{SBA}-15$ is accessible, reporting deactivation by reoxidation, as well. ${ }^{11}$

The origin of the $\mathrm{Ni}^{0}$ reoxidation on silica-based materials and not on alumina ones is not clearly addressed yet. We tentatively associate it to the distinct chemical properties of the used supports. A first reason most probably relies on the distinct acidic and/or basic features of these two oxides, alumina presenting both basic and acidic behaviours whereas silica is predominantly acidic. Another explanation could be the higher propensity of the alumina surface (compared to silica) to be hydroxylated and / hydrated upon contact with water (present in CSDRM as reactant and as possible side-reaction product), ${ }^{34}$ steam being therefore less available for oxidizing the metallic $\mathrm{Ni}$ nanoparticles as occurs on silica. ${ }^{33 b}$ To increase the reactivity of silica, we have tried, but without success, to include a hydrothermal treatment session ${ }^{35}$ during the SBA-15 synthesis (detailed in experimental section). Continuous work is in progress to clarify these points.

Concerning the "one-pot" $\mathrm{Ni}_{5 \%} \mathrm{Al}_{2} \mathrm{O}_{3}$ (meso) (best) catalyst, its high and stable performances are explained not only by the preservation of its $\mathrm{Ni}^{0}$ reduced state along reaction (as already stated above) but also by its excellent $\mathrm{Ni}$ dispersion also maintained after $40 \mathrm{~h}$ of testing. Indeed, the intensities of the $\mathrm{Ni}^{0}$ diffraction peaks of spent $\mathrm{Ni}_{5 \%} \mathrm{Al}_{2} \mathrm{O}_{3}$ (meso) (pattern d, Fig. $5 \mathrm{C}$ ) are similar to those before test (reduced catalyst (pattern d, Fig. 5B), except for a small contribution at $44.5^{\circ}$, signifying that the agglomeration of $\mathrm{Ni}$ nanoparticles was effectively avoided at a degree. As shown on a representative micrograph of spent $\mathrm{Ni}_{5 \%} \mathrm{Al}_{2} \mathrm{O}_{3}$ (meso) (Fig. 9E), the $\mathrm{Ni}$ metallic nanoparticles remained very small $(5.5 \mathrm{~nm})$, emphasizing the essential role of the initial nickel insertion within the ordered oxide framework ("one-pot" synthesis) towards avoiding metal nanoparticles growth during run. Such a confinement was furthermore confirmed by TEM images (Fig. 9F) showing Ni species as small as before run (Table 4), and by the corresponding Ni/Al atomic ratio 0.09-0.1. It seems therefore reasonable to correlate the stable performances of the mesoporous "one-pot" catalyst to the dominant initial presence of spinel nickel-aluminate phases exhibiting high MSI (as detected by TPR): these species lead, after reduction, to strongly anchored reduced $\mathrm{Ni}$-species that are stabilized within the ordered $\mathrm{Al}_{2} \mathrm{O}_{3}$, having strong resistance against sintering (and against reoxidation) even in presence of steam at
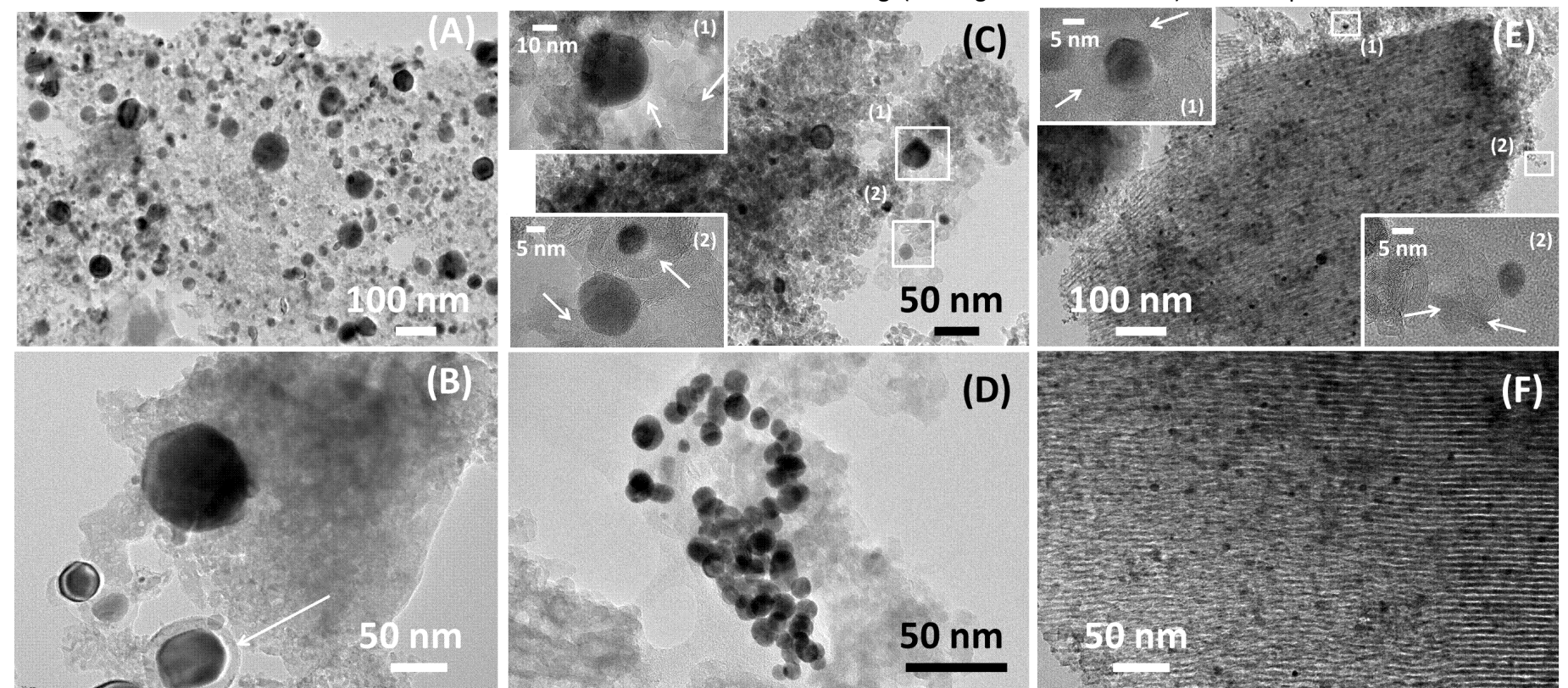

(D)

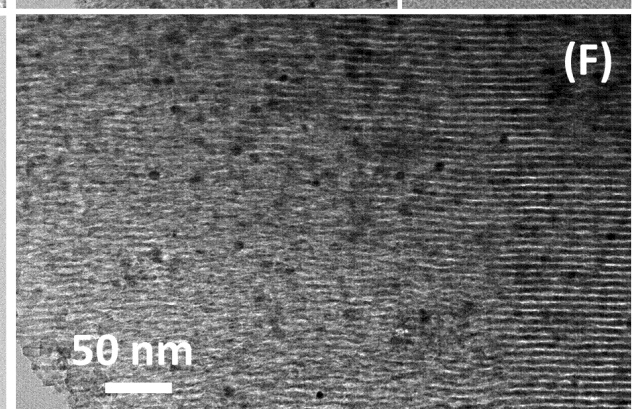

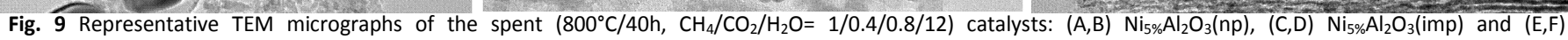

$\mathrm{Ni}_{5 \%} \mathrm{Al}_{2} \mathrm{O}_{3}$ (meso) catalysts. Carbon is marked with arrows. 
$800^{\circ} \mathrm{C}$. A similar positive effect was recently found in DRM over a catalyst containing solely mixed phases of $\mathrm{Ni}$ in $\mathrm{Al}_{2} \mathrm{O}_{3}{ }^{36}$

Finally, for spent $\mathrm{Ni}_{5 \%} \mathrm{Al}_{2} \mathrm{O}_{3}$ (imp), the partial collapse of its alumina mesostructure already present during preparation and reduction continued, and was even accentuated under the severe CSDRM testing conditions, causing further agglomeration of the already large $\mathrm{Ni}^{0}$ nanoparticles (very thin and intense peaks in pattern c, Fig. 5C; mean size values in Table 4). The nickel active phase is then no longer confined in a porous structure (Fig. 9C) and metal dispersion becomes highly heterogeneous ( $\mathrm{Ni} / \mathrm{Al}$ atomic ratios between 0.01 and 0.5), with some zones enriched in agglomerates of $\mathrm{Ni}$ nanoparticles co-present whereas others appear Ni free (Fig. 9D). The situation was even worse with the "one-pot" non-porous catalyst that displayed the strongest $\mathrm{Ni}$-metallic diffraction peaks after reaction (pattern b, Fig. 5C) and the highest degree of sintering with an average metallic particle sizes as big as 48-50 nm (as obtained from both XRD and TEM, Table 4). Similarly to the impregnated sample, very large as well as small species were visible on the external surface (Figs. $9(A, B)$ ), without any evidence of regular arrangement between them.

Finally, TGA/DTA/MS analyses of spent catalysts were carried out (data not detailed) to confirm the low coke contents suggested by all TEM pictures of spent samples (coke deposits rarely observed). They revealed a $\mathrm{C}_{(\mathrm{s})}$ wt\% loss decreasing in the following order: $(6 \%)$ $\mathrm{Ni}_{5 \%} \mathrm{Al}_{2} \mathrm{O}_{3}$ (meso) (5\%) Ni $\mathrm{N}_{5 \%} \mathrm{Al}_{2} \mathrm{O}_{3}(\mathrm{imp})>(0.5 \%) \mathrm{Ni}_{5 \%} \mathrm{Al}_{2} \mathrm{O}_{3}(\mathrm{np})$. Their matching DTA profiles, particularly those of "one-pot" $\mathrm{Ni}_{5 \%} \mathrm{Al}_{2} \mathrm{O}_{3}$ (meso) and $\mathrm{Ni}_{5 \%} \mathrm{Al}_{2} \mathrm{O}_{3}$ (imp) spent catalysts, showed a main exothermic peak at about $600^{\circ} \mathrm{C}$, attributed to the oxidation of graphitic carbon. ${ }^{37}$ The absence of any corresponding XRD diffraction peak was in line with the low contents of $C_{(s)}$ measured over all spent materials. However, it is worth noting that carbon formation was totally hindered inside the $\mathrm{Al}_{2} \mathrm{O}_{3}$ pores of the "onepot" $\mathrm{Ni}_{5 \%} \mathrm{Al}_{2} \mathrm{O}_{3}$ (meso) (Figs. $9(\mathrm{E}, \mathrm{F})$ ) due to steric constraints and stabilization of small $\mathrm{Ni}^{0}$ nanoparticles within the porous network during reaction. The very few particles that contributed in carbon formation appeared drift away from the support once the carbon nucleus was formed (insets in Fig. $9 \mathrm{E}$ ). In the case of spent $\mathrm{Ni}_{5 \%} \mathrm{Al}_{2} \mathrm{O}_{3}\left(\right.$ imp) and $\mathrm{Ni}_{5 \%} \mathrm{Al}_{2} \mathrm{O}_{3}(\mathrm{np})$, some agglomerated $\mathrm{Ni}^{0}$ species were seen completely encapsulated by multi-walled nano-onion carbon (insets in Fig. $9 \mathrm{C}$ and arrow on Fig. 9B), being no longer accessible to reactants. ${ }^{36}$ The lowest amount of $C_{(s)}$-deposits measured over the most deactivated sample (non-porous catalyst) is in line with its very poor activity.

\section{Conclusion}

A series of monometallic $5 \mathrm{wt} \% \mathrm{Ni}$ and porous or non-porous silica or alumina based-catalysts were successfully prepared and their reactivity was investigated in the combined methane reforming reaction at $800^{\circ} \mathrm{C}$. Reoxidation of the $\mathrm{Ni}^{0}$ active phase leading to deactivation was observed during reaction for silica based catalysts while the metallic nickel state was preserved in all alumina-based ones, even after 40h under stream. Mesoporous "one-pot" $\mathrm{Ni}_{5 \%} \mathrm{Al}_{2} \mathrm{O}_{3}$ (meso) compared to non-porous "one-pot" $\mathrm{Ni}_{5 \%} \mathrm{Al}_{2} \mathrm{O}_{3}$ (np) (both synthesized by EISA technique) showed significantly enhanced $\mathrm{Ni}$-alumina interaction as well as much smaller and well-confined $\mathrm{Ni}$ nanoparticles. This leads to a strongly improved sintering-resistance and to an excellent catalytic stability with CSDRM performances still close to the thermodynamic ones after $40 \mathrm{~h}$ on stream. The influence of the synthesis method was also considered by preparing a conventional impregnated $\mathrm{Ni}$ on mesoporous alumina catalyst $\mathrm{Ni}_{5 \%} \mathrm{Al}_{2} \mathrm{O}_{3}(\mathrm{imp})$ that was foud much less efficient. For clarification, Scheme 1 summarizes the main differences, in terms of state of the active phase, characterizing the alumina-based catalysts obtained by either "one-pot" synthesis approach or by traditional impregnation method. The metallic nickel nanoparticles are present both inside and outside the porous structure after postimpregnation whereas the "one-pot" technique favors a highly homogenous dispersion within the alumina matrix and consequently much smaller $\mathrm{Ni}^{0}$ nanoparticles with strengthened interaction with the support. The weakly attached $\mathrm{Ni}$ species (present mainly in the impregnated $\mathrm{Ni}_{5 \%} \mathrm{Al}_{2} \mathrm{O}_{3}$ (imp) catalyst) tend to sinter during both activation and reaction, resulting in agglomerated species which accelerate the rate of deactivation. The ordered "one-pot" mesoporous $\mathrm{Ni}_{5 \%} \mathrm{Al}_{2} \mathrm{O}_{3}$ (meso), synthesized by a simple one step method, appears as a very promising catalyst for combined methane reforming reaction.
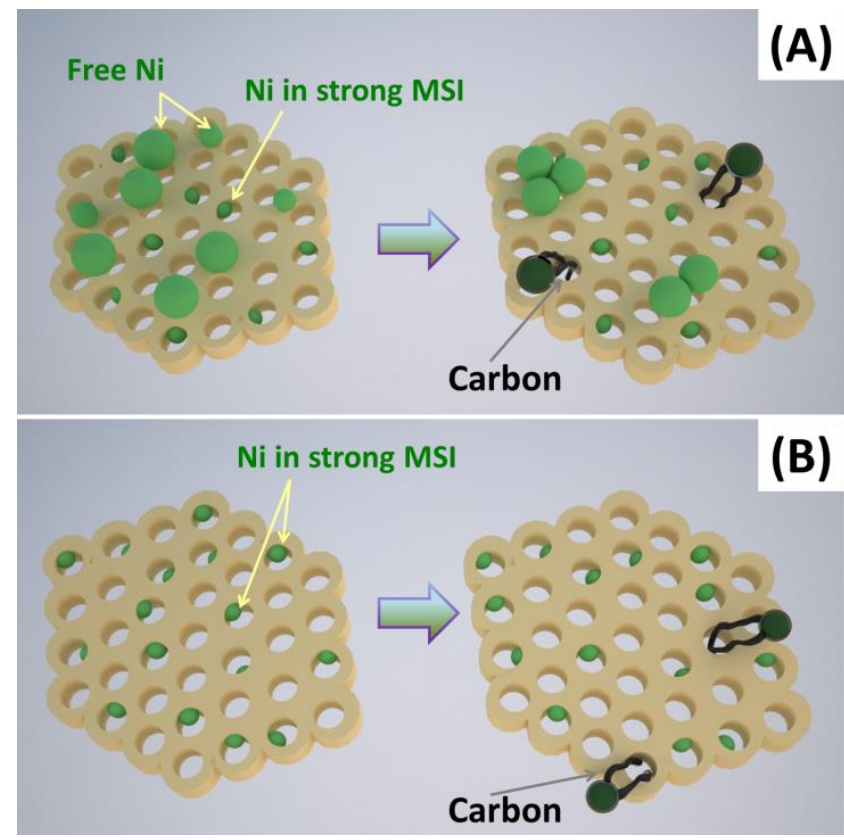

Scheme. 1 A graphical representation of: $(A)$ impregnated $\mathrm{Ni}_{5 \%} \mathrm{Al}_{2} \mathrm{O}_{3}(\mathrm{imp})$ and (B) "one-pot" $\mathrm{Ni}_{5 \%} \mathrm{Al}_{2} \mathrm{O}_{3}$ (meso) catalysts before (left) and after (right) the combined steam and dry reforming reaction.

\section{Acknowledgements}

The "Agence Universitaire de la Francophonie" and the Research Council of the University of Balamand are strongly acknowledged for partial K. Jabbour PhD funding (AUF fellowship and UOB 01/2013 BIRG, respectively). The authors are also sincerely grateful to the French-Lebanese CEDRE Hubert Curien program (PHC) for financial support to mobility (project number 30962ZH, 2014-2015). 


\section{References}

1 a) G. A. Olah, G. S. Prakash, A. Goeppert, M. Czaun, T. Mathew, J. Am. Chem. Soc., 2013, 135, 10030; b) G. A. Olah, A. Goeppert, M. Czaun, T. Mathew, R. B. May, G. S. Prakash, J. Am. Chem. Soc., 2015, 137, 8720; c) G. A. Olah, A. Goeppert, M. Czaun, G. S. Prakash, J. Am. Chem. Soc., 2013, 135,648 .

2 W. Wang, S. Wang, X. Ma, J. Gong, Chem. Soc. Rev., 2011, 40, 3703.

3 a) F. Pompeo, N. N. Nichio, M. M. V. M. Souza, D. V. Cesar, O. A. Ferretti, M. Schmal, Appl. Catal. A, 2007, 316, 175; b) M. C. J. Bradford, M. A. Vannice, Catal. Rev.Sci. Eng., 1999, 41, 1.

4 T. V. Choudhary, V. R. Choudhary, Angew. Chem., 2008, 47, 1828.

5 a) H. S. Roh, K. Y. Koo, J. H. Jeong, Y. T. Seo, D. J. Seo, Y. S. Seo, W. L. Yoon, S. B. Park, Catal. Lett., 2007, 117, 85; b) D. Qin, J. Lapszewicz, Catal. Today, 1994, 21, 551; c) D. Qin, J. Lapszewicz, X. Jiang, J. Catalysis, 1996, 159, 140; d) V. R. Choudhary, K. C. Mondal, Appl. Energy, 2006, 83, 1024; e) V. R. Choudhary, A. M. Rajput, Ind. Eng. Chem. Res., 1996, 35, 3934; f) V. R. Choudhary, B. S. Uphade, A. S. Mamman, Appl. Catal. A, 1998, 168, 33; g) J. B. Claridge, A. P. York, A. J. Brungs, J. Catal., 1998, 180, 85.

6 F. Yagi, A. Nagumo, Y. Wada, M. Shimura, US Pat. $6,387,843 B 1$.

7 a) S. S. Itkulova, G. D. Zakumbaeva, Y. Y. Nurmakanov, A. A. Mukazhanova, A. K. Yermaganbetova, Catal. Today, 2014 228, 194; b) H. S. Roh, K. Y. Koo, U. D. Joshi, W. L. Yoon, Catal. Lett., 2008, 125, 283; c) K. Y. Koo, H. S. Roh, Y. T. Seo, D. J. Seo, W. L. Yoon, S. B. Park, Appl. Catal. A, 2008, 340 183; d) K. Y. Koo, H. S. Roh, U. H. Jung, W. L. Yoon, Catal. Today, 2012, 185, 126; e) I. H. Son, S. J. Lee, A. Soon, H. S. Roh, H. Lee, Appl. Catal. B, 2013, 134, 103; f) M. GarcíaDiéguez, I. S. Pieta, M. C. Herrera, M. A. Larrubia, L. J. Alemany, Catal. Today, 2011, 172, 136; g) J. Mehz, K. J. Jozani, A. N. Pour, Y. Zamani, React. Kinet. Catal. Lett., 2002, 75, 267; h) K. M. Kang, I. W. Shim, H. Y. Kwak, Fuel. Process. Technol., 2012, 93, 105.

8 a) G. A. Olah, G. K. S. Prakash, US Pat. 7,906,559; b) G. A. Olah, G. K. S. Prakash, US Pat. 8,133,926; c) G. A. Olah, G. K. S. Prakash, US Pat. 8,440,729; d) G. A. Olah, G. K. S. Prakash US Pat. 8,697,759; e) G. A. Olah, G. K. S. Prakash, US Pat $8,980,961 ;$ f) G. A. Olah, G. K. S. Prakash, European Pat. $2,167,451 \mathrm{~A} 1$

9 a) K. Y. Koo, H. S. Roh, Y. T. Seo, D. J. Seo, W. L. Yoon, S. B. Park, Int. J. Hydrogen Energy, 2008, 33, 2036-2043; b) K. Y. Koo, S. H. Lee, U. H. Jung, H. S. Roh, W. L. Yoon, Fuel. Process. Technol., 2014, 119, 151; c) K. Y. Koo, H. S. Roh, U. H. Jung, D. J. Seo, Y. S. Seo, W. L. Yoon, Catal. Today, 2009, 146, 166; d) S. C. Baek, J. W. Bae, J. Y. Cheon, K. W. Jun, K. Y. Lee, Catal. Lett., 2011, 141, 224; e) J. W. Bae, A. R. Kim, S. C. Baek, K. W. Jun, React. Kinet. Catal. Lett., 2011, 104, 377; f) A. N. Pour, Y. Z. Kheirolah, J. Jozani, J. Y. Mehr, React. Kinet. Catal. Lett., 2005, 86, 157.

10 H. S. Roh, K. Y. Koo, W. L. Yoon, Catal. Today, 2009, 146, 71.

11 B. Huang, X. Li, S. Ji, B. Lang, F. Habimana, C. Li, J. Nat. Gas. Chem., 2008, 17, 225.

12 a) A. R. Kim, H. Y. Lee, D. H. Lee, B. W. Kim, C. H. Chung, D. J. Moon, E. J. Jang, C. Pang, J. W. Bae, Energy Fuels, 2015, 29, 1055.

13 M. M. Danilova, Z. A. Fedorova, V. A. Kuzmin, V. I. Zaikovskii, A. V. Porsin, T. A. Krieger, Catal. Sci. Technol., 2015, 5, 2761; b) M. M. Danilova, Z. A. Fedorova, V. I. Zaikovskii, A. V. Porsin, V. A. Kirillov, T. A. Krieger, Appl. Catal. B, 2014, 147, 858.
14 S. K. Ryi, S. W. Lee, J. W. Park, D. K. Oh, J. S. Park, S. S. Kim, Catal. Today, 2014, 236, 49.

15 a) M. A. Soria, C. Mateos-Pedrero, A. Guerrero-Ruiz, I. Rodríguez-Ramos, Int. J. Hydrogen Energy, 2011, 36, 15212; b) Ş. Özkara-Aydınoğlu, Int. J. Hydrogen Energy, 2010, 35, 12821 ; c) Y. Sun, T. Ritchie, S. S. Hla, S. McEvoy, W. Stein, J. H. Edwards, J. Nat. Gas. Chem., 2011, 20, 568; d) M. Jafarbegloo, A. Tarlani, A. W. Mesbah, S. Sahebdelfar, Int. J. Hydrogen Energy, 2015, 40, 2445; e) B. A. Santos, J. M. Loureiro, A. M. Ribeiro, A. E. Rodrigues, A. F. Cunha, Can. J. Chem. Eng., 2015, 93, 510.

16 S. Li, J. Gong, Chem. Soc. Rev., 2014, 43, 7245.

17 a) J. Sehested, J. A. P. Gelten, I. N. Remediakis, H. Bengaard, J. K. Nørskøv, J. Catal., 2004, 223, 432; b) J. Sehested, J. A. P. Gelten, S. Helveg, Appl. Catal., A 2006, 309, 237.

18 a) M. N. Kaydouh, N. El. Hassan, A. Davidson, S. Casale, P. Massiani, Micropor. Mesopor. Mat,. 2015, 220, 99; b) M. N. Kaydouh, N. El Hassan, A. Davidson, S. Casale, H. Zakhem, P. Massiani, C. R. Chim., 2015, 18, 293; c) N. Wang, Z. Xu, J. Deng, K. Shen, X. Yu, W. Qian, W. Chu, F. Wei, ChemCatChem, 2014, 6, 1470; d) X. Fang, C. Peng, H. Peng, W. Liu, X. Xu, X. Wang, C. Li, W. Zhou, ChemCatChem, 2015, 7, 3753; e) L. Xu, H. Sonf, L. Chou, Catal. Sci. Technol., 2011, $1,1032$.

19 a) W. Shen, K. Komatsubara, T. Hagiyama, A. Yoshida, S. Naito, Chem. Comm., 2009, 42, 6490; b) K. Wang, X. Li, S. Ji, X. Shi, J. Tang, Energy Fuels, 2008, 23, 25; c) H. Wan, X. Li, S. Ji, B. Huang, K. Wang, C. Li, J. Nat. Gas. Chem., 2007, 16, 139.

20 a) S. M. Morris, P. F. Fulvio, M. Jaroniec, J. Am. Chem. Soc., 2008, 130, 15210; b) Q. Yuan, A. X. Yin, C. Luo, L. D. Sun, Y. W. Zhang, W. T. Duan, H. C. Liu, C. H. Yan, J. Am. Chem. Soc., 2008, 130, 3465.

21 a) K. Jabbour, K., N. El Hassan, A. Davidson, P. Massiani, S. Casale, Chem. Eng. J.,2015, 264, 351.

22 a) M. Imperor-Clerc, D. Bazin, M. Appay, P. Beaunier, A. Davidson, Chem. Mater., 2004, 16, 1813; b) I. Lopes, N. El Hassan, H. Guerba, G. Wallez, A. Davidson, Chem. Mater., 2006, 18, 5826; c) J. Van der Meer, I. Bardez-Giboire, C. Mercier, B. Revel, A. Davidson, R. J. Denoyel, J. Phys. Chem. C, 2010, 114, 3507

23 a) D. Zhao, J. Feng, Q. Huo, N. Melosh, G. H. Fredrickson, B. F. Chmelka, G.D. Stucky, Science 1998, 279, 548; b) A. Sayari, A. Sayari, B. H. Han, Y. Yang, J. Am. Chem. Soc., 2004, 126, 14348.

24 T. Xie, L. Shi, J. Zhang, D. Zhang, Chem. Comm., 2014, 50, 7250.

25 J. A. C. Dias, J. M. Assaf, Catal. Today, 2003, 85, 59.

26 a) A. Zhao, W. Ying, H. Zhang, H. Ma, D. Fang, Catal. Commun., 2012, 17, 34; b) X. Zou, X. Wang, L. Li, K. Shen, X. Lu, W. Ding, Int. J. Hydrogen energy, 2010, 35, 12191; c) J. Zhang, H. Xu, X. Jin, Q. Ge, W. Li, Appl. Catal. A, 2005, 290, 87.

27 a) P. V. D. Voort, M. Benjelloun, E. F. Vansant, J. Phys. Chem. B, 2003, 106, 9027; b) J. Seo, M. Youn, D. Park, J. Jung, I. Song, Catal. Lett., 2009, 132, 395.

28 A. Grosman, C. Ortega, Langmuir, 2008, 24, 3977.

29 a) S. A. Bagshaw, I. J. Bruce, Micropor. Mesopor. Mat., 2008, 109, 199; b) S. Y. Chen, C. Y. Tang, J. F. Lee, L. Y. Jang, T. Tatsumi, S. Cheng, S. J. Mater. Chem., 2011, 21, 2255.

30 D. Kantorovich, L. Haviv, L. Vradman, M. V. Landau, Stud. Surf. Sci. Catal., 2005, 156, 147.

31 L. B. Sun, J. Yang, J. H. Kou, F. N. Gu, Y. Chun, Y. Wang, J. H. Zhu, Z. G. Zou, Angew. Chem. Int. Ed., 2008, 47, 3418.

32 a) J. Z. Luo, Z. L. Yu, C. F. Ng, C. T. Au, J. Catal. 2000, 194, 198; b) B. Kitiyanan, W. E. Alvarez, J. H. Harwell, D. E. Resasco, Chem. Phys. Lett., 2000, 317, 497.

33 a) M. A. Nieva, M. M. Villaverde, A. Monzón, T. F. Garetto, A. J. Marchi, Chem. Eng. J., 2014, 235, 158; b) Y. Matsumura, T. 
Nakamori, Appl. Catal. A, 2004, 258, 107; c) J. Majewski, J. Wood, W. Bujalski, Int. J. Hydrogen Energy, 2013, 38, 14531; d) H. Wan, X. Li, S. Ji, B. Huang, K. Wang, C. Li, J. Nat. Gas. Chem., 2007, 16, 139; e) K. Wang, X. Li, S. Ji, X. Shi, J. Tang, Energy Fuels, 2008, 23, 25; f) R. Takahashi, S. Sato, T. Sodesawa, M. Yoshida, S. Tomiyama, Appl. Catal. A, 2004, 273, 211.

34 a) Z. Liu, Y. Wang, J. Li, R. Zhang, RSC Advances, 2014, 26 225; b)L. Garcia, R. French, S. Czernik, E. Chornet, Appl. Catal. A, 2000, 201, 225.

35 F. Zhang, Y. Yan, H. Yang, Y. Yan, C. Yu, B. Tu, D. Zhao, J. Phys. Chem. B, 2005, 109, 8723.

36 L. Zhou, L. Li, N. Wei, J. Li, J. M. Basset, ChemCatChem, 2015, 16,2508

37 X.-Y. Quek, D. Liu, W. N. E. Cheo, H. Wang, Y. Chen, Y. Yang, Appl. Catal. B, 2010, 95, 374. 